\title{
Classification of Attention Deficit Hyperactivity Disorder (ADHD) Considering Diagnosis and Treatment
}

\author{
Sumathi M \\ Dept. of Information Science and Engineering, Don Bosco Institute of Technology, Bengaluru, India 560074 \\ Email: sumahalesh28@gmail.com \\ Dr. Nagaraj G Cholli \\ Dept. of Information Science and Engineering, R.V. College of Engineering, Bengaluru, India 560059 \\ Email: nagaraj.cholli@gmail.com \\ Dr. Shantharam Nayak \\ Dept. of Information Science and Engineering, R.V. College of Engineering, Bengaluru, India 560059 \\ Email: shantaram_nayak@yahoo.com
}

Received: 12 March 2019; Accepted: 22 April 2019; Published: 08 June 2019

\begin{abstract}
Attention Deficit Hyperactivity Disorder (ADHD) is the most frequent brain disorders in children. Brain is the greatest complicated data processing part in human body. ADHD can begin in childhood age and may extend till adolescent too. ADHD patients activities/actions/behaviour are totally different from non ADHD patients. To solve the problem in early stage is more precious contribution for children life. Otherwise the disorder may cause further destruction in child brain. An activity of ADHD child is: carelessness, impulsive, and feverish. These activities may be common in other children too but for ADHD patients these activities are more severe and more often occurs. ADHD can arise problems at school, home, it may affect children learning ability, and child may not join with others. ADHD is one among many childhood syndromes. The paper summarises the different ADHD diagnosis methods and suggested treatments for the disorder.
\end{abstract}

Index Terms - ADHD, Attention, hyperactive, diagnosis

\section{INTRODUCTION}

An ADHD syndrome is a critical medical problem for children. An ADHD child brain and its activities are different compare to normal child. An ADHD child syndrome leads to lose interest on any activities. The syndrome problem affects child at home, at study location, surrounding friends. Children has trouble to pay concentration, careful listen, follow instructions, sit quietly, simply stay for instructions. ADHD children struggle more in their daily life and it happens often. The most significant factor in this regard is to analyse the issues related to disorder and find the suitable remedy for the problem. This survey combines all the features related to ADHD disorder and some suggested solutions to the problem. There is a requirement of some sort of tool/application/game/analysis method to diagnose and to give treatment for ADHD. In an advanced technology robots are assisting children in learning process [1].

This survey is an opportunity to discover in depth about ADHD. The assessment related to ADHD leads to become close understanding of disorder, the current state, current/past work, symptoms, and solution techniques/methods of the disorder. ADHD symptoms are like anxiety, depression, self-injury etc. Considering these symptoms the motivated factor in this regard is children are facing the problem of ADHD, if it is not diagnosed and treated it continuous in adulthood too. In adulthood if the person is having all these symptoms then it leads to more complicated problems in her/his life for instance accidents, crime, angry etc. This is a significant area (ADHD) need to study the disorder and must provide necessary treatment for problems. The paper summarizes many fields which are related to ADHD.

\section{DifFERENT Diagnosis MethodS FOR ADHD}

In this section, we present the classification of different diagnosis methods for the ADHD disorder. Some techniques were introduced as a solution to ADHD. It does not require any blood sample, brain scan or any genetic screening procedure to diagnose the disorder. Moreover there is no specific test to identify disorder. Even it is difficult for doctors to evaluate and forecast the disorder before suggesting any medicine. The disorder is related to biology and brain, and need to remember it is not at all your fault. Some specific symptoms of disorder are simple to identify than other disorders or symptoms. Need to conduct diagnosis procedure followed by 
evaluation techniques for the disorder [2]. Hence, we have classified the different diagnosed methods. The disorder is classified based on many criteria such as diagnosis, treatment, symptoms, and techniques. Fig 1 shows the taxonomy of the classification.

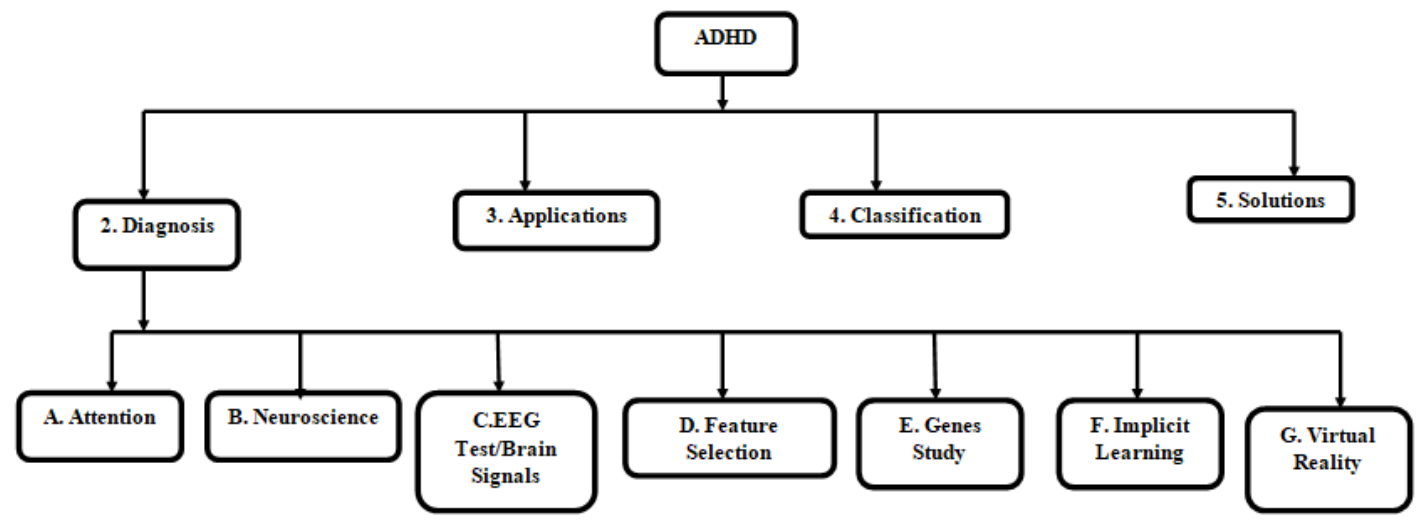

Fig.1. ADHD Classification Taxonomy

\section{A. Summary of adhd based on attention}

Kids are distracted when they have trouble in attention, concentration and difficult to stay on single task. When students have less attentive they may fail to listen directions, miss details, and the task is incomplete. Students look like absent minded and forgetful. The study [3] investigates the relation among preschool teaching faculty in addition to this sample of preschoolers also investigated. Table 1 gives the Summary of ADHD using Attention.

In ADHD attention is the crucial factor, children who are having disorder struggle to pay concentration at home, school. The work [3] gives importance for preschool children (147 male, 132 female), proves that the children whose close attachment with teacher secured good action, vision and listening skills. A single sweep analysis [4] method applied on 25 controlled and 25 ADHD boys and proved it is a sensitive method for investigation it has another advantage is group specific distinctions can also be measured. The crucial factor of ADHD is stress; Padmaja in their work [5] concentrated on stress using socio mobile data. And they identified features (closeness, eigenvector, and centrality) which boost stress level only in adults. As children grow they should adjust for each new environment, it is important too, work [6] describes developments in children while asking questions by designing schemas, and special case children were not included in homogeneous sampling. Using Deep Belief Network and greedy method Saeed [7] proved there is a maximum ADHD prediction accuracy can be achieved and that can be compared to other methods.

\section{B. Contribution of neuroscience for adhd diagnosis}

Moreover ADHD is brain related disorder. Neurologists found that problems such as anxiety, moody anger, and emotion are all results of defected neurotransmitters. Brain is divided into four blocks named as Frontal Cortex, Limbic System, Basal Ganglia and Reticular Activating System. All these parts are actively participates in ADHD patients. The research [8] shows how brainstem responses were collected and proves that these signals reduce mistakes while evaluating samples. Table 2 gives the Summary of ADHD using Neuroscience.

Human brain is the central processing unit of human body. In ADHD disorder brain and nervous system plays an important role. A Neurodevelopmental based work [9] using questionnaires for parents and children developed by Giovanna, investigated whether the child is having ADHD or not. An Immunological and neurotrophic markers [10] are used to find the risk level and illness which leads to ADHD, the drawback of the work is small number of high risk. An analysis of brain signals [11] is a crucial factor for $\mathrm{ADHD}$, paraconsistent procedure provides $80 \%$ of kappa index for ADHD, and still there is a scope for improvement of sensitivity factor. To increase the attention and meditation [12] neurofeedback is the suitable technique, it requires the design of 3D game with multiple factors. The work [13] shows that both cox and multi-state model for bipolar disorder results looks parallel. The work [14] on Socioeconomic Status (SES) proves that the disorder investigation and treatment must start in very early age, and the not concentrated on the effects of SES. The research [15] on Metacognitive interventions initiates the improvement of writing skills in school children, and less importance is given on teachers spent time for narrative writing. The work [16] on Dysfunctional neural proved that the abnormality in interregional connections for ADHD children. The study [17] includes the blood samples to study brain activities, and proves that these brain abnormalities assist to detect ADHD. 
Table 1. Summary of adhd using attention

\begin{tabular}{|c|c|c|c|c|c|c|}
\hline Literature Work & $\begin{array}{l}\text { Treatment } \\
\text { Method }\end{array}$ & Target Features & $\begin{array}{l}\text { Related } \\
\text { Platform }\end{array}$ & $\begin{array}{l}\text { Treatment } \\
\text { Accuracy }\end{array}$ & $\begin{array}{l}\text { Application } \\
\text { Useful for }\end{array}$ & Merits/Demerits \\
\hline $\begin{array}{l}\text { [3] Preschool teacher } \\
\text { attachment } \\
\text { and attention } \\
\text { skills }\end{array}$ & $\begin{array}{l}\text { Investigation } \\
\text { and Analysis }\end{array}$ & $\begin{array}{l}\text { Attention and } \\
\text { Concentration }\end{array}$ & $\begin{array}{l}\text { Descriptive } \\
\text { Analysis, } \\
\text { Mean } \\
\text { Comparison, } \\
\text { Pearson } \\
\text { Correlation } \\
\text { Matrix, } \\
\text { Regression } \\
\text { Analysis }\end{array}$ & $\begin{array}{l}\text { Children with } \\
\text { secure } \\
\text { attachments } \\
\text { \& higher } \\
\text { reaction } \\
\text { time }\end{array}$ & Children & $\begin{array}{l}\text { Attention } \\
\text { Improvement } \\
\text { in Children, } \\
\text { Limitations } \\
\text { in Observational } \\
\text { Instrument }\end{array}$ \\
\hline $\begin{array}{l}\text { [4]Single-Sweep } \\
\text { Analysis of Event- } \\
\text { Related Potentials } \\
\text { by Wavelet } \\
\text { Networks- } \\
\text { Methodological } \\
\text { Basis and Clinical } \\
\text { Application }\end{array}$ & Analysis & $\begin{array}{l}\text { Audio and } \\
\text { Attention }\end{array}$ & $\begin{array}{l}\text { Wavelet } \\
\text { Networks }\end{array}$ & $\begin{array}{l}\text { Reliable } \\
\text { single-sweep } \\
\text { estimates } \\
\text { could be } \\
\text { achieved by } \\
\text { the WN } \\
\text { approach }\end{array}$ & Children & $\begin{array}{l}\text { WN can be } \\
\text { recommended for } \\
\text { clinical study, for } \\
\text { larger and } \\
\text { more pronounced } \\
\text { N1 not possible } \\
\text { to obtain } \\
\text { measures }\end{array}$ \\
\hline $\begin{array}{l}\text { [5] TreeNet analysis of } \\
\text { human stress behavior } \\
\text { using socio-mobile } \\
\text { data }\end{array}$ & $\begin{array}{l}\text { mobile } \\
\text { phone } \\
\text { based social } \\
\text { interaction } \\
\text { features } \\
\text { using } \\
\text { TreeNet } \\
\text { machine } \\
\text { learning } \\
\text { algorithm } \\
\end{array}$ & Stress & $\begin{array}{l}\text { Mining, Social } \\
\text { Network } \\
\text { Analysis }\end{array}$ & $\begin{array}{l}\text { Proved } \\
\text { TreeNet is } \\
\text { more efficient }\end{array}$ & Adults & $\begin{array}{l}\text { Assists } \\
\text { economists, } \\
\text { professionals, } \\
\text { analysts, and } \\
\text { policy makers, } \\
\text { Worked on } \\
\text { Adults } \\
\text { only }\end{array}$ \\
\hline $\begin{array}{l}\text { [6] The Dusseldorf } \\
\text { Illustrated } \\
\text { Schema Questionnaire } \\
\text { for Children } \\
\text { (DISC) }\end{array}$ & $\begin{array}{l}\text { Questionnaire } \\
\text { and Cartoons } \\
\text { Design }\end{array}$ & $\begin{array}{l}\text { children } \\
\text { behaviour }\end{array}$ & $\begin{array}{l}\text { Statistical } \\
\text { analyses }\end{array}$ & $\begin{array}{l}\text { Early } \\
\text { maladaptive } \\
\text { schemas }\end{array}$ & Children & $\begin{array}{l}\text { Confirmatory } \\
\text { factor analysis } \\
\text { (CFA)showed } \\
\text { a satisfactory } \\
\text { goodness-of-fit, } \\
\text { clinical sample } \\
\text { not included } \\
\end{array}$ \\
\hline $\begin{array}{l}\text { [7] Diagnosis of } \\
\text { Attention } \\
\text { Deficit Hyperactivity } \\
\text { Disorder Using } \\
\text { Deep Belief Network } \\
\text { Based on Greedy } \\
\text { Approach }\end{array}$ & $\begin{array}{l}\text { fMRI Image } \\
\text { Features }\end{array}$ & NeuroImage & $\begin{array}{l}\text { Machine } \\
\text { Learning, } \\
\text { Greedy } \\
\text { Algorithm }\end{array}$ & $\begin{array}{l}\text { Proved } \\
\text { method is } \\
\text { Superior than } \\
\text { other }\end{array}$ & Children & $\begin{array}{l}\text { Superior Method } \\
\text { but limited to } \\
\text { children }\end{array}$ \\
\hline
\end{tabular}

Table 2. Summary of adhd using neuroscience process

\begin{tabular}{|l|l|l|l|l|l|l|}
\hline Literature Work & $\begin{array}{l}\text { Treatment } \\
\text { Method }\end{array}$ & $\begin{array}{l}\text { Target } \\
\text { Features }\end{array}$ & Related Platform & $\begin{array}{l}\text { Treatment } \\
\text { Accuracy }\end{array}$ & $\begin{array}{l}\text { Application } \\
\text { Useful for }\end{array}$ & Merits/Demerits \\
\hline $\begin{array}{l}\text { [9]Neurodevelopmental } \\
\text { outcomes of moderately } \\
\text { preterm birth: } \\
\text { precursors of attention } \\
\text { deficit }\end{array}$ & Assessment & $\begin{array}{l}\text { Behavioural } \\
\text { Development } \\
\text { atperactivity disorder }\end{array}$ & $\begin{array}{l}\text { Specific } \\
\text { Questionnaires }\end{array}$ & $\begin{array}{l}\text { Results with } \\
\text { problematic } \\
\text { functioning } \\
\text { profiles for } \\
\text { Patients }\end{array}$ & Children & $\begin{array}{l}\text { Shows presence of } \\
\text { a } \\
\text { profile for } \\
\text { children, yet to } \\
\text { relate for } \\
\text { paediatric-health } \\
\text { field }\end{array}$ \\
\hline $\begin{array}{l}{[10] \text { Immunological and }} \\
\text { neurotrophic markers of } \\
\text { risk }\end{array}$ & $\begin{array}{l}\text { mRNA } \\
\text { status and illness } \\
\text { development in high- } \\
\text { risk youth: } \\
\text { understanding the } \\
\text { neurobiological } \\
\text { underpinnings } \\
\text { of bipolar disorder }\end{array}$ & $\begin{array}{l}\text { Collection of } \\
\text { Genes }\end{array}$ & $\begin{array}{l}\text { Linear Regression, } \\
\text { novel clinical } \\
\text { staging model }\end{array}$ & $\begin{array}{l}\text { Only } \\
\text { BDNF(brain- } \\
\text { derived } \\
\text { neurotrophic } \\
\text { factor) protein } \\
\text { levels remained } \\
\text { significant. }\end{array}$ & Mean Age & $\begin{array}{l}\text { Support for } \\
\text { detectable } \\
\text { differences in } \\
\text { candidate immune } \\
\text { and neurotrophic } \\
\text { markers, minimal } \\
\text { confounding with } \\
\text { exposure to } \\
\text { medical }\end{array}$ \\
\hline
\end{tabular}




\begin{tabular}{|c|c|c|c|c|c|c|}
\hline $\begin{array}{l}\text { [11]Paraconsistent } \\
\text { neurocomputing and } \\
\text { brain signal analysis }\end{array}$ & $\begin{array}{l}\text { Clinical } \\
\text { diagnosis, } \\
\text { Image } \\
\text { analysis }\end{array}$ & Behavior & $\begin{array}{l}\text { Artificial neural } \\
\text { network, EEG } \\
\text { analysis, Pattern } \\
\text { recognition }\end{array}$ & $\begin{array}{l}\text { Result of } \\
\text { recognition is } \\
80 \%\end{array}$ & $\begin{array}{l}\text { Adults, } \\
\text { Children }\end{array}$ & $\begin{array}{l}\text { Study gives good } \\
\text { result for ADHD, } \\
\text { Yet to implement } \\
\text { real time analysis }\end{array}$ \\
\hline $\begin{array}{l}\text { [12]Neurofeedback } \\
\text { Based Attention } \\
\text { Training for Children } \\
\text { with ADHD }\end{array}$ & $\begin{array}{l}\text { Observation } \\
\text { of } \\
\text { Brainwave }\end{array}$ & Behavior & $\begin{array}{l}\text { Analysis of pre and } \\
\text { post training } \\
\text { parameters }\end{array}$ & $\begin{array}{l}\text { Helps to realize } \\
\text { the problems of } \\
\text { children }\end{array}$ & Children & $\begin{array}{l}\text { System gives } \\
\text { feedback and } \\
\text { improves ADHD, } \\
\text { system } \\
\text { concentrates only } \\
\text { children }\end{array}$ \\
\hline $\begin{array}{l}\text { [13]Multi-state models } \\
\text { for investigating } \\
\text { possible } \\
\text { stages leading to bipolar } \\
\text { disorder }\end{array}$ & $\begin{array}{l}\text { Investigation } \\
\text { and Analysis }\end{array}$ & $\begin{array}{l}\text { Non Mood, } \\
\text { Minor, Major } \\
\text { Moods }\end{array}$ & $\begin{array}{l}\text { Cox models, } \\
\text { Statistical Analysis }\end{array}$ & $\begin{array}{l}\text { Cox and multi- } \\
\text { state model are } \\
\text { useful approach } \\
\text { to antecedent } \\
\text { risk } \\
\text { syndromes. }\end{array}$ & $\begin{array}{l}\text { Adults, } \\
\text { Children }\end{array}$ & $\begin{array}{l}\text { To assess } \\
\text { longitudinal } \\
\text { variables Cox } \\
\text { model is best suited } \\
\text { /familial } \\
\text { correlation can be } \\
\text { included. }\end{array}$ \\
\hline $\begin{array}{l}\text { [14]Influence of family } \\
\text { socioeconomic status } \\
\text { on IQ, language, } \\
\text { memory and executive } \\
\text { functions of Brazilian } \\
\text { children }\end{array}$ & Assessment & $\begin{array}{l}\text { IQ and } \\
\text { performance } \\
\text { in tasks } \\
\text { that assess } \\
\text { language, } \\
\text { verbal } \\
\text { memory, } \\
\text { working } \\
\text { memory } \\
\text { and } \\
\text { executive } \\
\text { functions. }\end{array}$ & $\begin{array}{l}\text { Neuropsychological } \\
\text { assessment, }\end{array}$ & $\begin{array}{l}\text { socioeconomic } \\
\text { status (SES) } \\
\text { had stronger } \\
\text { effects on } \\
\text { younger } \\
\text { children }\end{array}$ & Children & $\begin{array}{l}\text { Prevent difficulties } \\
\text { in } \\
\text { children's } \\
\text { neurocognitive } \\
\text { development / SES } \\
\text { should be } \\
\text { considered } \\
\text { in the divisions of } \\
\text { normative groups } \\
\text { of } \\
\text { neuropsychological } \\
\text { tests. }\end{array}$ \\
\hline $\begin{array}{l}{[15] \text { Metacognitive }} \\
\text { interventions in text } \\
\text { production and working } \\
\text { memory in } \\
\text { students with ADHD }\end{array}$ & $\begin{array}{l}\text { Comparison } \\
\text { using } \\
\text { writing, } \\
\text { memory } \\
\text { status } \\
\text { behaviour of } \\
\text { students }\end{array}$ & $\begin{array}{l}\text { Behaviour } \\
\text { and } \\
\text { Performance }\end{array}$ & $\begin{array}{l}\text { (Diagnostic and } \\
\text { Statistical } \\
\text { Manual )DSM-IV } \\
\text { criteria }\end{array}$ & $\begin{array}{l}\text { To improve } \\
\text { behaviour and } \\
\text { school } \\
\text { performance }\end{array}$ & $\begin{array}{l}\text { Students age } \\
\text { around } 13\end{array}$ & $\begin{array}{l}\text { combined } \\
\text { intervention } \\
\text { improves writing, } \\
\text { no evaluation was } \\
\text { conducted on the } \\
\text { maintenance of the } \\
\text { effects for longer } \\
\text { periods }\end{array}$ \\
\hline $\begin{array}{l}\text { [16]Dysfunctional } \\
\text { neural activity and } \\
\text { connection patterns in } \\
\text { attention } \\
\text { deficit hyperactivity } \\
\text { disorder: A resting state } \\
\text { fMRI study }\end{array}$ & $\begin{array}{l}\text { Comparison, } \\
\text { Analysis }\end{array}$ & $\begin{array}{l}\text { Brain } \\
\text { Samples }\end{array}$ & $\begin{array}{l}\text { Amplitude of low } \\
\text { frequency } \\
\text { fluctuation (ALFF) } \\
\text { and functional } \\
\text { connections }\end{array}$ & $\begin{array}{l}\text { The } \\
\text { abnormalities } \\
\text { in prefrontal } \\
\text { and temporal } \\
\text { cortex might } \\
\text { gives evidence. }\end{array}$ & Around 11 & $\begin{array}{l}\text { DMN and PHG } \\
\text { could be related to } \\
\text { the } \\
\text { pathophysiological } \\
\text { mechanisms of } \\
\text { ADHD, Treatment } \\
\text { can be extended to } \\
\text { above } 11 \text { years too }\end{array}$ \\
\hline $\begin{array}{l}\text { [17]Functional Network } \\
\text { Disruption in Attention } \\
\text { Deficit } \\
\text { Hyperactivity Disorder }\end{array}$ & $\begin{array}{l}\text { Brain } \\
\text { functional } \\
\text { network } \\
\text { Sample } \\
\text { comparision }\end{array}$ & $\begin{array}{l}\text { Functional } \\
\text { imaging data, } \\
\text { the resting } \\
\text { state fMRI } \\
\text { data }\end{array}$ & $\begin{array}{l}\text { Functional } \\
\text { Networks } \\
\text { Construction }\end{array}$ & $\begin{array}{l}\text { Results shows } \\
\text { less optimized } \\
\text { smallworldness } \\
\text { organization } \\
\text { was found in } \\
\text { ADHD }\end{array}$ & $\begin{array}{l}\text { Children } \\
\text { around } 11 \\
\text { years }\end{array}$ & $\begin{array}{l}\text { results of } \\
\text { degree values and } \\
\text { hub nodes showed } \\
\text { a deficit in the } \\
\text { prefront } \\
\text { cortex, Samples } \\
\text { need to support } \\
\text { disconnected or } \\
\text { sparse graphs. }\end{array}$ \\
\hline
\end{tabular}

\section{Classification of applications using eeg test/brain signals}

Electroencephalography plays an important role to assess and evaluate the disorder of ADHD. Human actions are related to neural functions. Many researchers adopted this main tool to diagnose ADHD in their research. Applying of EEG signal is a familiar method towards the improvements in the sustained attention levels of children by designing videogames [18]. Table 3 gives the Summary of ADHD using EEG Test Signal.
The study [19] uses the symbolic dynamic procedure to detect ADHD in children, and results $86 \%$ of classification accuracy among AHDH and non ADHD children, input subjects number can be increased to get more accurate results. A research [20] on brain activity using EEG signals proved ADHD subjects are lower beta activations compared to non ADHD subjects, the study includes very less numbers subjects (total seven). The work [21] uses analysis of magnetoencephalographic data to record the brain state during idle and active mode, method can be improved by considering more number of 
dataset (current is 8). The work [22] proves the stigmatizing nature is very sensitive in teachers compare to other participants, the work not included teacher's background such as education, training etc. The study [23] analysis of EEG data uses mutual information and the classifier achieves $85.7 \%$ accuracy to detect ADHD in children. The work [24] uses dynamic deep learning technique to segregate the ADHD and ASD patients separately in very less time duration with $96 \%$ of classification rate. The study [25] uses EEG signal to identify ADHD and achieved high accuracy of $87.5 \%$ in rest state. The work [26] designed an unsupervised learning algorithm with game using multiple levels, each level gives result as average and it leads to more accurate result for different levels.

\section{Classification of applications using feature selection}

A variety of features related to ADHD may impair the daily life functions of children and adults. It is crucial to select accurate features in each method. A research [27] on characterization of ADHD using integrated feature ranking and selection and achieved minimum number of features in the last mode by applying novel integrated feature ranking and selection framework. Feature selection method using Relief algorithm and verification accuracy to classify ADHD [28] and achieved higher accuracy. Table 4 gives the Summary of ADHD using Feature Selection.

The work [29] uses a concept called feature selection to divide ADHD and non ADHD patient's features, and it gives less importance for changes in EEG features. The work [30] gesture recognition model allows finding behaviour patterns which are defined by physicians and provides a satisfactory result. The study [31] compared cobalt level in urine sample, result proved that cobalt is not at all responsible for the presence of ADHD disorder. The study [32] uses EEG and wavelet analysis to construct a model which is capable to separate ADHD and non ADHD with 94.74\% accuracy. The work [33] uses quantitative data to list students profiles, the profiles leads to identify where students finding difficult to linguistic, cognitive and environmental natures.

Table 3. Summary of Adhd Using Eeg Test Signal

\begin{tabular}{|c|c|c|c|c|c|c|}
\hline Literature Work & $\begin{array}{l}\text { Treatment } \\
\text { Method }\end{array}$ & Target Features & $\begin{array}{l}\text { Related } \\
\text { Platform }\end{array}$ & $\begin{array}{l}\text { Treatment } \\
\text { Accuracy }\end{array}$ & $\begin{array}{l}\text { Application } \\
\text { Useful for }\end{array}$ & Merits/Demerits \\
\hline $\begin{array}{l}\text { [19]Detecting ADHD } \\
\text { Children Using } \\
\text { Symbolic Dynamic of } \\
\text { Nonlinear } \\
\text { Features of EEG }\end{array}$ & $\begin{array}{l}\text { nonlinear features } \\
\text { of EEG }\end{array}$ & Visual Samples & $\begin{array}{l}\text { symbolic } \\
\text { dynamics } \\
\text { method }\end{array}$ & $\begin{array}{l}\text { Classification } \\
\text { accuracy is } \\
86 \% \text { between } \\
\text { ADHD and } \\
\text { control group }\end{array}$ & Children & $\begin{array}{l}\text { Proves attention } \\
\text { is important for } \\
\text { classification, } \\
\text { maximum and } \\
\text { minimum } \\
\text { attention can be } \\
\text { considered }\end{array}$ \\
\hline $\begin{array}{l}\text { [20]EEG analysis of } \\
\text { brain activity in } \\
\text { Attention Deficit } \\
\text { Hyperactivity Disorder } \\
\text { during an Attention } \\
\text { task }\end{array}$ & $\begin{array}{l}\text { Analysis of brain } \\
\text { activity }\end{array}$ & Attention & $\begin{array}{l}\text { Non- } \\
\text { parametric } \\
\text { statistical } \\
\text { analysis }\end{array}$ & $\begin{array}{l}\text { Reduction in } \\
\text { beta activity }\end{array}$ & Children & $\begin{array}{l}\text { Higher theta/beta } \\
\text { ratio for ADHD, } \\
\text { Total number of } \\
\text { Sample can be } \\
\text { increased. }\end{array}$ \\
\hline $\begin{array}{l}\text { [21]Low Frequency } \\
\text { Phase Synchronisation } \\
\text { Analysis Of } \\
\text { Meg Recordings From } \\
\text { Children With Adhd } \\
\text { And } \\
\text { Controls Using Single } \\
\text { Channel Ica }\end{array}$ & Analysis & MEG Recordings & $\begin{array}{l}\text { Single Channel } \\
\text { ICA and Phase } \\
\text { Synchrony }\end{array}$ & $\begin{array}{l}\text { variations in } \\
\text { the phase } \\
\text { locking and } \\
\text { phase } \\
\text { synchrony }\end{array}$ & Children & $\begin{array}{l}\text { Negative } \\
\text { components leads } \\
\text { to lapses in } \\
\text { attention, need to } \\
\text { include more } \\
\text { datasets. }\end{array}$ \\
\hline $\begin{array}{l}\text { [22]Stigmatization in } \\
\text { teachers towards } \\
\text { adults with attention } \\
\text { deficit hyperactivity } \\
\text { disorder }\end{array}$ & questionnaire & Stigma Response & $\begin{array}{l}\text { Statistical } \\
\text { analysis }\end{array}$ & $\begin{array}{l}\text { Teachers are } \\
\text { more } \\
\text { sensitized } \\
\text { attitude } \\
\text { than ADHD } \\
\text { adults }\end{array}$ & Adults & $\begin{array}{l}\text { Teachers } \\
\text { demonstrated } \\
\text { more sensitized } \\
\text { attitude, clarity } \\
\text { of teachers } \\
\text { characteristics }\end{array}$ \\
\hline $\begin{array}{l}\text { [23]Mutual } \\
\text { Information Analysis } \\
\text { of EEG of Children } \\
\text { with Attention- } \\
\text { Deficit/Hyperactivity } \\
\text { Disorder }\end{array}$ & Analysis & $\begin{array}{l}\text { neuropsychologic } \\
\text { al deviation }\end{array}$ & $\begin{array}{l}\text { Classification, } \\
\text { Mutual } \\
\text { Information, } \\
\text { Feature } \\
\text { Selection }\end{array}$ & $\begin{array}{l}\text { classifier } \\
\text { achieved } \\
\text { accuracy of } \\
85.7 \%\end{array}$ & Children & $\begin{array}{l}\text { Combination of } \\
\text { with appropriate } \\
\text { feature selection } \\
\text { algorithm MI } \\
\text { gives Best } \\
\text { Result, Number } \\
\text { of subjects can be } \\
\text { increased to get } \\
\text { better result. }\end{array}$ \\
\hline
\end{tabular}




\begin{tabular}{|c|c|c|c|c|c|c|}
\hline $\begin{array}{l}\text { [24]Automatic } \\
\text { Detection of ADHD } \\
\text { and ASD from } \\
\text { Expressive Behaviour } \\
\text { in } \\
\text { RGBD Data }\end{array}$ & questionnaire & $\begin{array}{l}\text { Behaviour } \\
\text { Analysis }\end{array}$ & Deep Learning, & $\begin{array}{l}\text { Directly } \\
\text { predict ADHD } \\
\text { and ASD in } \\
\text { adults. }\end{array}$ & Adults & $\begin{array}{l}\text { System can be } \\
\text { used clinically, } \\
\text { Dedicated for } \\
\text { adults }\end{array}$ \\
\hline $\begin{array}{l}\text { [25]Non-linear EEG } \\
\text { Analysis in Children } \\
\text { with } \\
\text { Attention-Deficit/ } \\
\text { Hyperactivity Disorder } \\
\text { During the Rest } \\
\text { Condition }\end{array}$ & $\begin{array}{l}\text { Investigation, } \\
\text { Feature } \\
\text { Extraction }\end{array}$ & EEG Signal & $\begin{array}{l}\text { Probabilistic } \\
\text { Neural } \\
\text { Network, } \\
\text { Largest } \\
\text { Lyapunov } \\
\text { Exponent, } \\
\text { Approximate } \\
\text { Entropy }\end{array}$ & $\begin{array}{l}87.5 \% \text { for } \\
\text { identification } \\
\text { of ADHD }\end{array}$ & Children & $\begin{array}{l}\text { Results yields a } \\
\text { high accuracy to } \\
\text { identify ADHD, } \\
\text { Data rate }(10+12) \\
\text { can be increased } \\
\text { to get better } \\
\text { results }\end{array}$ \\
\hline $\begin{array}{l}\text { [26]Assess Autism } \\
\text { Level While Playing } \\
\text { Games }\end{array}$ & $\begin{array}{l}\text { Anxiety, motor } \\
\text { skill }\end{array}$ & Activity Pattern & Fuzzy Logic & $\begin{array}{l}\text { Algorithm } \\
\text { achieved } 85 \% \\
\text { accuracy. }\end{array}$ & Children & $\begin{array}{l}\text { Method can be } \\
\text { used globally, } \\
\text { More number of } \\
\text { students }(50) \text { can } \\
\text { be considered for } \\
\text { study. }\end{array}$ \\
\hline
\end{tabular}

Table 4. Summary of adhd using feature selection

\begin{tabular}{|c|c|c|c|c|c|c|}
\hline Literature Work & $\begin{array}{l}\text { Treatment } \\
\text { Method }\end{array}$ & Target Features & $\begin{array}{l}\text { Related } \\
\text { Platform }\end{array}$ & $\begin{array}{l}\text { Treatment } \\
\text { Accuracy }\end{array}$ & $\begin{array}{l}\text { Application } \\
\text { Useful for }\end{array}$ & Merits/Demerits \\
\hline $\begin{array}{l}\text { [29]Personalized } \\
\text { Features for Attention } \\
\text { Detection in Children } \\
\text { with } \\
\text { Attention Deficit } \\
\text { Hyperactivity Disorder }\end{array}$ & $\begin{array}{l}\text { EEG Recorded } \\
\text { Data }\end{array}$ & Attention & $\begin{array}{l}\text { Feature } \\
\text { Extraction, } \\
\text { Classification, }\end{array}$ & $\begin{array}{l}\text { It is } \\
\text { information } \\
\text { only for } \\
3.26 \% \text { of } \\
\text { ADHD } \\
\text { children). }\end{array}$ & Children & $\begin{array}{l}\text { Features selected } \\
\text { are most } \\
\text { important } \\
\text { measures to } \\
\text { detect } \\
\text { attention on } \\
\text { average, Can be } \\
\text { experimented } \\
\text { (120) with more } \\
\text { children }\end{array}$ \\
\hline $\begin{array}{l}\text { [30]A Gesture } \\
\text { Recognition System } \\
\text { for Detecting } \\
\text { Behavioural Patterns } \\
\text { of ADHD }\end{array}$ & $\begin{array}{l}\text { Gesture } \\
\text { Recognition }\end{array}$ & Behaviour & $\begin{array}{l}\text { Gaussian } \\
\text { mixture } \\
\text { models } \\
\text { (GMMs), } \\
\text { multimodal } \\
\text { RGB-depth } \\
\text { data. } \\
\end{array}$ & $\begin{array}{l}\text { Statistical } \\
\text { improvements }\end{array}$ & Children & $\begin{array}{l}\text { Provides } \\
\text { information to } \\
\text { clinicians, not } \\
\text { applicable to } \\
\text { large amounts of } \\
\text { data }\end{array}$ \\
\hline $\begin{array}{l}\text { [31]Optoelectronics } \\
\text { method for } \\
\text { determining the } \\
\text { cobalt involved in } \\
\text { symptoms of attention } \\
\text { deficit hyperactivity } \\
\text { disorder }\end{array}$ & $\begin{array}{l}\text { Children Urine } \\
\text { Sample collection }\end{array}$ & $\begin{array}{l}\text { Concentration of } \\
\text { cobalt in urine }\end{array}$ & $\begin{array}{l}\text { GF-AAS, } \\
\text { Analysis }\end{array}$ & $\begin{array}{l}\text { Proved cobalt } \\
\text { cannot be } \\
\text { responsible for } \\
\text { the presence } \\
\text { of ADHD } \\
\text { symptoms. }\end{array}$ & $\begin{array}{l}\text { Children } \\
\text { (Male and } \\
\text { Female) }\end{array}$ & $\begin{array}{l}\text { Method is simple } \\
\text { and reproducible, } \\
\text { Designed only } \\
\text { for children }\end{array}$ \\
\hline $\begin{array}{l}\text { [32] Identification of } \\
\text { ADHD Cognitive } \\
\text { Pattern Disturbances } \\
\text { Using EEG and } \\
\text { Wavelets } \\
\text { Analysis }\end{array}$ & $\begin{array}{l}\text { Analysis, } \\
\text { Investigation }\end{array}$ & Brain Signals & $\begin{array}{l}\text { Weka Tool, } \\
\text { Matlab, SVM }\end{array}$ & $\begin{array}{l}\text { Achieved } \\
94.74 \% \text { of } \\
\text { accuracy. }\end{array}$ & Children & $\begin{array}{l}\text { Model capable of } \\
\text { classifying } \\
\text { ADHD } \\
\text { individuals, } \\
\text { selected only } 19 \\
\text { collaborators }(9+1 \\
0)\end{array}$ \\
\hline $\begin{array}{l}\text { [33]Causes of } \\
\text { academic and } \\
\text { behavioural difficulties } \\
\text { among Japanese- } \\
\text { Brazilian students: } \\
\text { cognitive, } \\
\text { linguistic and parental } \\
\text { education factors }\end{array}$ & $\begin{array}{l}\text { Given Tasks, } \\
\text { Questionnaires }\end{array}$ & Behaviour & $\begin{array}{l}\text { Mann- } \\
\text { Whitney } \\
\text { analysis, }\end{array}$ & $\begin{array}{l}\text { Provides clear } \\
\text { information } \\
\text { about } \\
\text { students' } \\
\text { linguistic, } \\
\text { cognitive and } \\
\text { environmental } \\
\text { profiles }\end{array}$ & Children & $\begin{array}{l}\text { Results can be } \\
\text { used to solve } \\
\text { problems of } \\
\text { students who are } \\
\text { experiencing } \\
\text { difficulties }\end{array}$ \\
\hline
\end{tabular}

\section{E. Classification of applications using genes study}

Researchers even proved that there is a strong relationship/association of genetics in ADHD. A research carried out by Emili Banerjee [34] gene interaction related to $\mathrm{ADHD}$, and proved $95 \% \mathrm{CI}$ risk of ADHD. Table 5 gives the Summary of ADHD using Genes Study
The study [35] called prioritization of candidate genes for ADHD which involves neurotransmitter, nervous system and gives result as 16 candidate genes for future replication. The work [36] involves total of 238 cases and in this only 57 cases were matched.

\section{F. Classification of applications using implicit learning}


Two major types of implicit learning methods are sequence learning and spatial contextual learning. The sequence learning methods is type of repeated occurrences of experiences and spatial contextual learning is related to spatial relationship. A research [37] conducted on preschool children using implicit learning method and achieved tremendous difference between ADHD and non ADHD children. Table 6 gives the Summary of ADHD using implicit learning.

The work [38] uses implicit knowledge on people to identify who gained the knowledge and who are not, here the triple response time is neglected. The study [39] shows the child art psychotherapy is the method to diagnose anxiety, behaviour and ADHD disorders in 28\%, $25 \%$ and $21 \%$ respectively.

\section{G. Classification of applications using virtual reality}

Virtual Reality (VR) is an interactive method especially for ADHD children, in assistance with computer children may feel they are in the real world. This is one of the crucial tools as a solution to disorder. VR is the realistic and an instant action for children. A research [40] is a treatment procedure for ADHD by designing an interface in assistance with P300 and VR, and achieved average error rate below $30 \%$. In VR brain computer interface is a method, in assistance a system is designed with six subjects and achieved error rate below 0.30 [41]. Table 7 gives the Summary of ADHD using Virtual Reality.

A work [42] uses virtual reality to assess and test ADHD, result shows deeper level of diagnosis, this can be enhanced using feature extraction of eye tracking and EEG data. Another novel method [43] uses virtual reality to assess ADHD, results are verified with different aspects, the large scale verification need to do.

\section{DifFERENT APPLICATION FOR ADHD}

In today world children are addicted to mobiles, it is a serious issue. Different types of applications are designed with various electronic devices including computer and mobiles. Among many SanppyApp is the application designed for ADHD children and adults, and shows how to balance risk in addition providing health information [44] . Table 8 gives the Summary of ADHD Applications.

The work [45] designed a video game, which shows the combination of AR and DGBL makes inclusion of children towards learning process, need to test the game with different environments. The study [46] uses video game for 20 kids and result shows that students are motivated towards learning process, further need to observe AR and DGBL and game design principles need to be tested. The work [47] multi touch surface assists to improve concentration and impulse control, proper conclusions not taken. The study [48] uses robot to observe human behaviour and achieved $80 \%$ accuracy, need to remove some of the restrictions. A cross word puzzle game [49] helps to improve certain skills in children, enhancement to current system is expanding the game with new set of feature. The approach [50] proposes gene set analysis procedure to detect any nominal effects, the limitation is usage of the system is not appropriate. A framework [51] Web Health Application for ADHD Monitoring (WHAAM) supports to count and measure the behaviour parameters of ADHD. A method [52] adaptive neuro-electrostimulation used to improve children attention, memory, functions and behaviour for ADHD disorder. Using the web [53] data about ADHD provides features of disorder, the method provides awareness among people. A video image [54] method applied on children aged between 3-6 with different stages, results shows that there is a remarkable change in stage 3 , and these data can be used in clinics for the analysis of disorder.

Table 5. Summary of adhd using genes study

\begin{tabular}{|c|c|c|c|c|c|c|}
\hline Literature Work & $\begin{array}{l}\text { Treatment } \\
\text { Method }\end{array}$ & Target Features & $\begin{array}{l}\text { Related } \\
\text { Platform }\end{array}$ & $\begin{array}{l}\text { Treatment } \\
\text { Accuracy }\end{array}$ & $\begin{array}{l}\text { Application } \\
\text { Useful for }\end{array}$ & Merits/Demerits \\
\hline $\begin{array}{l}\text { [35] Prioritization of } \\
\text { candidate genes for } \\
\text { attention } \\
\text { deficit hyperactivity } \\
\text { disorder by } \\
\text { computational analysis } \\
\text { of multiple data } \\
\text { sources }\end{array}$ & Analysis & $\begin{array}{l}\text { Gene } \\
\text { prioritization }\end{array}$ & $\begin{array}{l}\text { ToppNet, Heat } \\
\text { map matrix }\end{array}$ & $\begin{array}{l}\text { Facilitate the } \\
\text { exploration of } \\
\text { pathogenesis } \\
\text { mechanism of } \\
\text { ADHD }\end{array}$ & Candidates & $\begin{array}{l}\text { Only } 16 \\
\text { promising } \\
\text { ADHD genes } \\
\text { were considered }\end{array}$ \\
\hline $\begin{array}{l}\text { [36]Mother Smoking } \\
\text { During Pregnancy and } \\
\text { ADHD in Children }\end{array}$ & Survey & $\begin{array}{l}\text { data on physical } \\
\text { activity and } \\
\text { fitness levels }\end{array}$ & $\begin{array}{l}\text { NHANES, } \\
\text { NNYFS }\end{array}$ & $\begin{array}{l}\text { Proved mother } \\
\text { smoking } \\
\text { during } \\
\text { pregnancy } \\
\text { increases risk } \\
\text { for ADHD in } \\
\text { children }\end{array}$ & $\begin{array}{l}\text { Children } \\
\text { average age } \\
10.7\end{array}$ & $\begin{array}{l}\text { Additional efforts } \\
\text { should be added } \\
\text { to prove ADHD } \\
\text { in association } \\
\text { with other } \\
\text { smoking during } \\
\text { pregnancy }\end{array}$ \\
\hline
\end{tabular}


Table 6. Summary of adhd using implicit learning

\begin{tabular}{|c|c|c|c|c|c|c|}
\hline Literature Work & $\begin{array}{l}\text { Treatment } \\
\text { Method }\end{array}$ & Target Features & $\begin{array}{l}\text { Related } \\
\text { Platform }\end{array}$ & $\begin{array}{l}\text { Treatment } \\
\text { Accuracy }\end{array}$ & $\begin{array}{l}\text { Application } \\
\text { Useful for }\end{array}$ & Merits/Demerits \\
\hline $\begin{array}{l}\text { [38] Response Time } \\
\text { Analysis on Implicit } \\
\text { Learning } \\
\text { Induced by Cognitive } \\
\text { Tasks Toward } \\
\text { Developing } \\
\text { ADHD Treatment }\end{array}$ & Analysis & Response Time & $\begin{array}{l}\text { Implicit } \\
\text { Learning. } \\
\text { Cognitive tasks }\end{array}$ & $\begin{array}{l}\text { Result shows } \\
\text { distinction } \\
\text { between } \\
\text { people who } \\
\text { had } \\
\text { gained } \\
\text { implicit } \\
\text { knowledge } \\
\text { and those did } \\
\text { not. }\end{array}$ & Children & $\begin{array}{l}\text { Method is crucial } \\
\text { for designing the } \\
\text { Neurofeedback } \\
\text { treatment } \\
\text { to help those } \\
\text { with ADHD }\end{array}$ \\
\hline $\begin{array}{l}\text { [39]Child art } \\
\text { psychotherapy in } \\
\text { CAMHS: } \\
\text { Which cases are } \\
\text { referred and which } \\
\text { cases drop out? }\end{array}$ & Analysis & $\begin{array}{l}\text { Anxiety, } \\
\text { behaviour }\end{array}$ & $\begin{array}{l}\text { Classification, } \\
\text { CAP }\end{array}$ & $\begin{array}{l}\text { Anxiety } \\
\text { disorder (28 } \\
\%) \text {, behaviour } \\
\text { disorder (25 } \\
\%) \text {, and } \\
\text { ADHD }(21 \%)\end{array}$ & $\begin{array}{l}\text { Children age } \\
\text { range from } \\
5 \text { to } 17\end{array}$ & $\begin{array}{l}\text { No significant } \\
\text { difference in the } \\
\text { percentage of } \\
\text { males in } \\
\text { comparison to } \\
\text { females }\end{array}$ \\
\hline
\end{tabular}

Table 7. Summary of adhd using virtual reality

\begin{tabular}{|l|l|l|l|l|l|l|}
\hline Literature Work & $\begin{array}{l}\text { Treatment } \\
\text { Method }\end{array}$ & Target Features & $\begin{array}{l}\text { Related } \\
\text { Platform }\end{array}$ & $\begin{array}{l}\text { Treatment } \\
\text { Accuracy }\end{array}$ & $\begin{array}{l}\text { Application } \\
\text { Useful for }\end{array}$ & Merits/Demerits \\
\hline $\begin{array}{l}\text { [42] ADHD } \\
\text { Assessment and } \\
\text { Testing System Design } \\
\text { on Virtual Reality }\end{array}$ & $\begin{array}{l}\text { Analysis, Eye } \\
\text { tracking, EEG } \\
\text { Signals }\end{array}$ & concentration & $\begin{array}{l}\text { CPT, Virtual } \\
\text { Reality }\end{array}$ & $\begin{array}{l}\text { System may } \\
\text { provide a } \\
\text { deeper level of } \\
\text { ADHD } \\
\text { diagnosis and } \\
\text { cognitive } \\
\text { rehabilitation. }\end{array}$ & Children & $\begin{array}{l}\text { Results assists to } \\
\text { identify ADHD, } \\
\text { Deep learning } \\
\text { may be included }\end{array}$ \\
\hline $\begin{array}{l}\text { [43]An Innovative } \\
\text { ADHD Assessment } \\
\text { System Using }\end{array}$ & $\begin{array}{l}\text { Assessment, } \\
\text { Diagnosis }\end{array}$ & $\begin{array}{l}\text { Listening test, } \\
\text { CPT test, } \\
\text { executive test, } \\
\text { and } \\
\text { visual memory } \\
\text { test }\end{array}$ & $\begin{array}{l}\text { Virtual reality, } \\
\text { executive } \\
\text { function, HMD }\end{array}$ & $\begin{array}{l}\text { Study } \\
\text { successfully } \\
\text { develops a } \\
\text { novel VR } \\
\text { technology }\end{array}$ & $\begin{array}{l}\text { Children age } \\
\text { range 7 to } \\
13\end{array}$ & $\begin{array}{l}\text { The functionality } \\
\text { of the system } \\
\text { in various } \\
\text { aspects, Clinical } \\
\text { trial need to be } \\
\text { added }\end{array}$ \\
\hline
\end{tabular}

\section{Different ClassificAtion Methods For ADHD}

One category of classification is in terms of ADHD children and non ADHD children. Another classification involves diagnosing the disorder using real and simulated data. A test called statistical independence [55] assists to diagnose the ADHD problem efficiently between predicted and real data samples. Table 9 gives the Summary of ADHD Classification methods.

A work [56] uses 56 ADHD patients among then 26 age child and 26 are adolescents, the results shows different behaviour patterns for hyperactivity and impulsivity. The method [57] uses neural network to identify the different types of ADHD, LVQ2NN gives $80 \%$ and GA-LVQ2NN 95\% of average accuracy. An auditory visual stimulation [58] system shows there is a difference between ADHD and non ADHD children, and ADHD children show decreased attention over time. A method two way ANOVA [59] is used to find the differences between ADHD and non ADHD children, results shows there is a significant difference between them in response time, need to record speed of visualization it gives more accurate result. An AutoRegressive (AR) [60] mechanism assists to categorize ADHD and non ADHD with $85 \%$ to $95 \%$ accuracy. Applying Deep Bayesian [61] network method the features such as control, inattentiveness, hyperactive, combined are analyzed and proved is the best method for classification. A machine leaning techniques [62] such as Classification and Regression Trees (CART) and Chisquare Automatic Interaction Detector(CHAID) is used to classify ADHD and OSA, result shows that CART method is better computational procedure compare to CHAID. The work [63] uses emotion recognition data to classify ADHD, ASD and control group based on response time, results shows $90 \%$ of accuracy for classification. An angular velocity sensors and acceleration [64] method used to compare the hand movement of ADHD and healthy children, results are represented using radar chart, need to include more subjects for the analysis of the problem. Using Hemodynamic [65] responses and the children reaction time classified ADHD and non ADHD children, less comparison is done on hyperactive-impulsive. Modified dual tree [66] complex waveform technique is used to differentiate ADHD and normal children using three methods (Frame Difference, Pixel by Pixel Method, Image XOR), among them Image XOR takes very less time for computation. An EEG mapping and brain connectivity [67] used to study the abnormalities of ADHD children, and results shows a deviation in brain map for ADHD compare to non ADHD children. A novel feature extraction [68] method uses Extreme Learning Machine to classify ADHD and non ADHD children, 
result shows improved accuracy for classification, still

there is a scope to analyze neuroimaging data.

Table 8. Summary of adhd applications

\begin{tabular}{|c|c|c|c|c|c|c|}
\hline Literature Work & $\begin{array}{l}\text { Treatment } \\
\text { Method }\end{array}$ & Target Features & $\begin{array}{l}\text { Related } \\
\text { Platform }\end{array}$ & $\begin{array}{l}\text { Treatment } \\
\text { Accuracy }\end{array}$ & $\begin{array}{l}\text { Application } \\
\text { Useful for }\end{array}$ & Merits/Demerits \\
\hline $\begin{array}{l}\text { [45] Using a } \\
\text { Videogame with } \\
\text { Augmented Reality for } \\
\text { an } \\
\text { Inclusive Logical } \\
\text { Skills Learning } \\
\text { Session }\end{array}$ & Game design & $\begin{array}{l}\text { Students } \\
\text { Performance }\end{array}$ & $\begin{array}{l}\text { Augmented } \\
\text { Reality, } \\
\text { Inclusive } \\
\text { Learning, } \\
\text { Mathematics, } \\
\text { Learning }\end{array}$ & $\begin{array}{l}\text { Students } \\
\text { strongly } \\
\text { motivate } \\
\text { towards } \\
\text { learning } \\
\text { process }\end{array}$ & Children & $\begin{array}{l}\text { Need to } \\
\text { experiment on } \\
\text { other } \\
\text { environments }\end{array}$ \\
\hline $\begin{array}{l}\text { [46]Gremlings in my } \\
\text { Mirror: An Inclusive } \\
\text { AR-Enriched } \\
\text { Videogame for } \\
\text { Logical Math } \\
\text { Skills Learning }\end{array}$ & $\begin{array}{l}\text { Observation and } \\
\text { comparison }\end{array}$ & Performance & $\begin{array}{l}\text { Augmented } \\
\text { Reality, } \\
\text { Inclusive } \\
\text { Learning, } \\
\text { Mathematics, } \\
\text { Learning }\end{array}$ & $\begin{array}{l}\text { AR and } \\
\text { DGBL allow } \\
\text { the integration } \\
\text { of children } \\
\text { with } \\
\text { special needs } \\
\text { in the learning } \\
\text { process }\end{array}$ & Children & $\begin{array}{l}\text { strongly } \\
\text { motivated in the } \\
\text { learning process, } \\
\text { principles have } \\
\text { yet to be fine- } \\
\text { tuned and proven } \\
\text { in other } \\
\text { experiences }\end{array}$ \\
\hline $\begin{array}{l}\text { [47]Adaptive Training } \\
\text { of Children with } \\
\text { Attention Deficit } \\
\text { Hyperactivity Disorder } \\
\text { through Multi-touch } \\
\text { Surfaces }\end{array}$ & Training, therapy & $\begin{array}{l}\text { Concentration, } \\
\text { impulse control }\end{array}$ & $\begin{array}{l}\text { Adaptive } \\
\text { training, } \\
\text { CAPTAIN }\end{array}$ & $\begin{array}{l}\text { Help patients } \\
\text { to improve } \\
\text { their abilities } \\
\text { regarding } \\
\text { concentration } \\
\text { and impulse } \\
\text { control }\end{array}$ & $\begin{array}{l}\text { Children, } \\
\text { Adults }\end{array}$ & $\begin{array}{l}\text { AdaptADHD } \\
\text { gives promising } \\
\text { results, can be } \\
\text { used for } \\
\text { diagnosis }\end{array}$ \\
\hline $\begin{array}{l}\text { [48]Deep Recurrent Q- } \\
\text { Learning of } \\
\text { Behavioral } \\
\text { Intervention Delivery } \\
\text { by a } \\
\text { Robot from } \\
\text { Demonstration Data }\end{array}$ & Robot Design & Behaviour & $\begin{array}{l}\text { DRQN, LfD } \\
\text { framework }\end{array}$ & $\begin{array}{l}\text { With } 80 \% \\
\text { accuracy }\end{array}$ & $\begin{array}{l}\text { Designed } \\
\text { for children }\end{array}$ & $\begin{array}{l}\text { Proved deep Q- } \\
\text { learning seems } \\
\text { an appropriate } \\
\text { tool to solve } \\
\text { many LfD } \\
\text { problems, deliver } \\
\text { an automated } \\
\text { version of } \\
\text { DRQN model }\end{array}$ \\
\hline $\begin{array}{l}\text { [49] Guided } \\
\text { Crossword-Puzzle } \\
\text { Games aimed at } \\
\text { Children } \\
\text { with Attentional } \\
\text { Deficit: Preliminary } \\
\text { Results }\end{array}$ & Game design & $\begin{array}{l}\text { Parameter } \\
\text { collection, } \\
\text { screening }\end{array}$ & GUI Design & $\begin{array}{l}\text { Guided } \\
\text { exercises are a } \\
\text { key feature in } \\
\text { the } \\
\text { development } \\
\text { of autonomous } \\
\text { therapies for } \\
\text { children with } \\
\text { ADHD. }\end{array}$ & Children & $\begin{array}{l}\text { Inclusion of new } \\
\text { exercises needed }\end{array}$ \\
\hline $\begin{array}{l}\text { [50] Efficient and } \\
\text { Powerful Method for } \\
\text { Combining } \\
\text { P-Values in Genome- } \\
\text { Wide Association } \\
\text { Studies }\end{array}$ & Algorithm design & genetic variants & $\begin{array}{l}\text { adaptive rank } \\
\text { truncated } \\
\text { product } \\
\text { method, } \\
\text { cyclophilin } \\
\text { domain, } \\
\text { extreme value } \\
\text { theory, } \\
\text { R function } \\
\text { globalEVT, }\end{array}$ & $\begin{array}{l}\text { The new } \\
\text { approach } \\
\text { improves } \\
\text { power by } \\
\text { allowing } \\
\text { different } \\
\text { inheritance } \\
\text { models for } \\
\text { each } \\
\text { genetic variant }\end{array}$ & $\begin{array}{l}\text { School } \\
\text { Children }\end{array}$ & $\begin{array}{l}\text { Its use is not } \\
\text { appropriate when } \\
\text { the genetic } \\
\text { association is due } \\
\text { to epistasis } \\
\text { and not to } \\
\text { marginal effects }\end{array}$ \\
\hline $\begin{array}{l}\text { [51] The Future of } \\
\text { Mobile Health ADHD } \\
\text { Applications }\end{array}$ & $\begin{array}{l}\text { Designed Mobile } \\
\text { Application }\end{array}$ & $\begin{array}{l}\text { Monitor } \\
\text { behaviour }\end{array}$ & $\begin{array}{l}\text { mobile } \\
\text { applications, } \\
\text { WHAAM } \\
\text { application }\end{array}$ & $\begin{array}{l}\text { WHAAM app } \\
\text { provides tools } \\
\text { for } \\
\text { evaluation of } \\
\text { intervention } \\
\text { efficacy }\end{array}$ & Children & $\begin{array}{l}\text { WHAAM } \\
\text { provides } \\
\text { counting and } \\
\text { measuring } \\
\text { behaviour's } \\
\text { parameters } \\
\text { to ADHD, Need } \\
\text { to use big data } \\
\text { concept }\end{array}$ \\
\hline
\end{tabular}




\begin{tabular}{|c|c|c|c|c|c|c|}
\hline $\begin{array}{l}\text { [52]Application of the } \\
\text { Non-invasive Adaptive } \\
\text { Neuroelectrostimulatio } \\
\mathrm{n} \\
\text { Device for Treatment } \\
\text { of Cognitive } \\
\text { Impairment in the } \\
\text { Model of Attention } \\
\text { Deficit } \\
\text { Hyperactivity Disorder }\end{array}$ & $\begin{array}{l}\text { Treatment } \\
\text { procedure, } \\
\text { DCASNS } \\
\text { method, gold } \\
\text { standard }\end{array}$ & $\begin{array}{l}\text { attention, } \\
\text { working memory, } \\
\text { executive } \\
\text { functions } \\
\text { and behaviour } \\
\text { control }\end{array}$ & $\begin{array}{l}\text { SYMPATHOC } \\
\text { OR-01 device; } \\
\text { neuromodulati } \\
\text { on; } \\
\text { neurorehabilita } \\
\text { tion; } \\
\text { neuroelectrosti } \\
\text { mulation }\end{array}$ & $\begin{array}{l}\text { Proved } \\
\text { research using } \\
\text { neuroimaging } \\
\text { techniques } \\
\text { is required to } \\
\text { confirm the } \\
\text { assumptions. }\end{array}$ & Children & $\begin{array}{l}\text { There was } \\
\text { significant } \\
\text { improvement in } \\
\text { attention, } \\
\text { working } \\
\text { memory, } \\
\text { executive } \\
\text { functions } \\
\text { and behaviour } \\
\text { control in } \\
\text { children with } \\
\text { ADHD, } \\
\text { Considered only } \\
72 \text { children }\end{array}$ \\
\hline $\begin{array}{l}\text { [53]Seeking Web- } \\
\text { Based Information } \\
\text { About Attention } \\
\text { Deficit } \\
\text { Hyperactivity } \\
\text { Disorder: Where, } \\
\text { What, and When }\end{array}$ & $\begin{array}{l}\text { Data collection } \\
\text { through web }\end{array}$ & Analysis & $\begin{array}{l}\text { Internet; search } \\
\text { engine; coping } \\
\text { behaviour }\end{array}$ & $\begin{array}{l}\text { Proved } \\
\text { Internet is } \\
\text { indeed a } \\
\text { source of } \\
\text { information } \\
\text { about ADHD }\end{array}$ & Children & $\begin{array}{l}\text { The } \\
\text { classification } \\
\text { criteria as well as } \\
\text { interrater validity } \\
\text { need to further } \\
\text { be discussed and } \\
\text { improved. }\end{array}$ \\
\hline $\begin{array}{l}\text { [54] Body Movement } \\
\text { in Children with } \\
\text { ADHD Calculated } \\
\text { Using Video } \\
\text { Images }\end{array}$ & $\begin{array}{l}\text { Body movements } \\
\text { data collected } \\
\text { using image } \\
\text { processing }\end{array}$ & $\begin{array}{l}\text { Sleep Patterns, } \\
\text { Body movements }\end{array}$ & $\begin{array}{l}\text { PSG and video } \\
\text { monitoring. }\end{array}$ & $\begin{array}{l}\text { Proved } \\
\text { differences in } \\
\text { body } \\
\text { movement } \\
\text { during sleep in } \\
\text { normal } \\
\text { children and } \\
\text { those with } \\
\text { ADHD }\end{array}$ & $\begin{array}{l}\text { Children } \\
\text { total } 17 \\
(11+6)\end{array}$ & $\begin{array}{l}\text { In SWS, children } \\
\text { with } \\
\text { ADHD are more } \\
\text { unstable than } \\
\text { normally } \\
\text { developed } \\
\text { children } \\
\text { are, need to } \\
\text { develop a new } \\
\text { monitoring } \\
\text { system at home. }\end{array}$ \\
\hline
\end{tabular}

Table 9. Summary of adhd classification methods

\begin{tabular}{|c|c|c|c|c|c|c|}
\hline Literature Work & $\begin{array}{l}\text { Treatment } \\
\text { Method }\end{array}$ & Target Features & $\begin{array}{l}\text { Related } \\
\text { Platform }\end{array}$ & $\begin{array}{l}\text { Treatment } \\
\text { Accuracy }\end{array}$ & $\begin{array}{l}\text { Application } \\
\text { Useful for }\end{array}$ & Merits/Demerits \\
\hline $\begin{array}{l}\text { [56]Differences in } \\
\text { connectivity patterns } \\
\text { between child and } \\
\text { adolescent } \\
\text { attention deficit } \\
\text { hyperactivity disorder } \\
\text { patients }\end{array}$ & $\begin{array}{l}\text { Demographic } \\
\text { DATA collection }\end{array}$ & Brain activity & $\begin{array}{l}\text { Network } \\
\text { construction, } \\
\text { Connectivity } \\
\text { analysis, } \\
\text { Connectivity } \\
\text { pattern, } \\
\text { Statistical } \\
\text { analysis }\end{array}$ & $\begin{array}{l}\text { Proved child } \\
\text { and adolescent } \\
\text { ADHD } \\
\text { patients show } \\
\text { different } \\
\text { behaviour } \\
\text { patterns, such } \\
\text { as } \\
\text { hyperactive/i } \\
\text { mpulsivity } \\
\end{array}$ & $\begin{array}{l}\text { Children, } \\
\text { adults }\end{array}$ & $\begin{array}{l}\text { The results } \\
\text { provide novel } \\
\text { information to } \\
\text { further ADHD } \\
\text { related } \\
\text { neuroimaging } \\
\text { studies }\end{array}$ \\
\hline $\begin{array}{l}\text { [57]The Performance } \\
\text { Of Genetic Algorithm } \\
\text { Learning } \\
\text { Vector Quantization } 2 \\
\text { Neural Network On } \\
\text { Identification Of The } \\
\text { Types Of Attention } \\
\text { Deficit } \\
\text { Hyperactivity Disorder }\end{array}$ & $\begin{array}{l}\text { Performance } \\
\text { comparison }\end{array}$ & $\begin{array}{l}\text { The data used as } \\
\text { many as } 100 \text { with } \\
45 \text { symptoms of } \\
\text { ADHD }\end{array}$ & $\begin{array}{l}\text { genetic } \\
\text { algorithm; } \\
\text { LVQ2; neural } \\
\text { network }\end{array}$ & $\begin{array}{l}\text { GA-LVQ2NN } \\
\text { method gives } \\
\text { accuracy, that } \\
\text { is } 89.5 \% \text { and } \\
\text { LVQ2 method } \\
\text { gives } 80 \% \text {. }\end{array}$ & Children & $\begin{array}{l}\text { The result shows } \\
\text { that GA can be } \\
\text { combined with } \\
\text { LVQ2NN }\end{array}$ \\
\hline $\begin{array}{l}\text { [58]Sustained attention } \\
\text { differences between } \\
\text { children with } \\
\text { ADHD and normal } \\
\text { children based on } \\
\text { auditory-visual } \\
\text { stimulation }\end{array}$ & $\begin{array}{l}\text { Auditory-visual, } \\
\text { comparison }\end{array}$ & $\begin{array}{l}\text { Attention and } \\
\text { time }\end{array}$ & $\begin{array}{l}\text { auditory } \\
\text { stimulation, } \\
\text { visual } \\
\text { stimulation, } \\
\text { sustained } \\
\text { attention, } \\
\text { Statistical } \\
\text { analysis }\end{array}$ & $\begin{array}{l}\text { ADHD } \\
\text { children show } \\
\text { a significant } \\
\text { downward } \\
\text { trend over } \\
\text { time }\end{array}$ & Children & $\begin{array}{l}\text { Method shows } \\
\text { improvements in } \\
\text { length of time } \\
\text { and task } \\
\text { difficulty, } \\
\text { experimental } \\
\text { procedure is not } \\
\text { set to run full- } \\
\text { screen }\end{array}$ \\
\hline
\end{tabular}




\begin{tabular}{|c|c|c|c|c|c|c|}
\hline $\begin{array}{l}{[59] \text { The Differences in }} \\
\text { Coordination between } \\
\text { Children } \\
\text { with ADHD and } \\
\text { Healthy Children } \\
\text { Based on Twoway } \\
\text { ANOVA Analysis }\end{array}$ & Analysis & $\begin{array}{l}\text { Interaction in } \\
\text { hand movements' } \\
\text { rhythm, accuracy }\end{array}$ & $\begin{array}{l}\text { Grouping, } \\
\text { movement } \\
\text { coordination }\end{array}$ & $\begin{array}{l}\text { Shows that } \\
\text { children with } \\
\text { ADHD are } \\
\text { easier to make } \\
\text { mistakes while } \\
\text { doing complex } \\
\text { tasks }\end{array}$ & Children & $\begin{array}{l}\text { There is no } \\
\text { difference in } \\
\text { reaction time } \\
\text { between children } \\
2974 \\
\text { with ADHD and } \\
\text { normal children, } \\
\text { needs } \\
\text { further } \\
\text { experimental } \\
\text { verification }\end{array}$ \\
\hline $\begin{array}{l}\text { [60]Classification of } \\
\text { ADHD and Non- } \\
\text { ADHD Using AR } \\
\text { Models }\end{array}$ & Classification, & $\begin{array}{l}\text { Accuracy and } \\
\text { confidence }\end{array}$ & Classification & $\begin{array}{l}\text { Achieved } \\
\text { accuracy } 85- \\
95 \%\end{array}$ & $\begin{array}{l}\text { Children age } \\
6 \text { to } 8\end{array}$ & $\begin{array}{l}\text { A confidence } \\
\text { metric is } \\
\text { proposed, } \\
\text { expressing with } \\
\text { how much } \\
\text { confidence the } \\
\text { classification of } \\
\text { ADHD and non- } \\
\text { ADHD subjects } \\
\text { is made. }\end{array}$ \\
\hline $\begin{array}{l}\text { [61]Discrimination of } \\
\text { ADHD children based } \\
\text { on Deep Bayesian } \\
\text { Network }\end{array}$ & Feature selection & $\begin{array}{l}\text { Brain areas } \\
\text { feature }\end{array}$ & $\begin{array}{l}\text { Deep Learning, } \\
\text { Bayesian } \\
\text { Network, SVM }\end{array}$ & $\begin{array}{l}\text { Secured best } \\
\text { results in } \\
\text { ADHD-200 } \\
\text { competition }\end{array}$ & Children & $\begin{array}{l}\text { Still there is a } \\
\text { scope to choose } \\
\text { the different } \\
\text { brain areas as the } \\
\text { input of Bayesian } \\
\text { Network }\end{array}$ \\
\hline $\begin{array}{l}\text { [62]Machine Learning } \\
\text { Approach for } \\
\text { Distinction of ADHD } \\
\text { and OSA }\end{array}$ & Questionnaires & Behaviour, sleep & $\begin{array}{l}\text { Machining } \\
\text { learning, } \\
\text { Neural } \\
\text { Network }\end{array}$ & $\begin{array}{l}\text { Results show } \\
\text { that CART } \\
\text { model } \\
\text { has better } \\
\text { computational } \\
\text { efficiency than } \\
\text { CHAID } \\
\end{array}$ & $\begin{array}{l}\text { Children age } \\
\text { between } 6 \text { to } \\
12 \text { in the } \\
\text { year } 2011 \text { to } \\
2015\end{array}$ & $\begin{array}{l}\text { The method } \\
\text { helps to } \\
\text { happy to learn } \\
\text { and to better } \\
\text { focus on } \\
\text { schoolwork }\end{array}$ \\
\hline $\begin{array}{l}\text { [63]ADHD and ASD } \\
\text { Classification Based } \\
\text { on Emotion } \\
\text { Recognition Data }\end{array}$ & $\begin{array}{l}\text { Showing images } \\
\text { of faces and } \\
\text { asking questions }\end{array}$ & $\begin{array}{l}\text { Response } \\
\text { Latency }\end{array}$ & $\begin{array}{l}\text { Human- } \\
\text { computer } \\
\text { interaction, } \\
\text { Classification,e } \\
\text { motion } \\
\text { recognition, } \\
\text { machine } \\
\text { learning } \\
\end{array}$ & $\begin{array}{l}\text { Achieved } \\
90 \%, 80 \% \\
\text { accuracy for } \\
\text { different } \\
\text { combinations }\end{array}$ & $\begin{array}{l}\text { Children } \\
\text { average age } \\
\text { of } 10.5 \text {, } \\
9.46 \text {, and } \\
9.22\end{array}$ & $\begin{array}{l}\text { Best performance } \\
\text { is obtained for } \\
\text { the adhd others } \\
\text { group on } \\
\text { response time } \\
\text { data }\end{array}$ \\
\hline $\begin{array}{l}\text { [64]The comparison } \\
\text { with the function of } \\
\text { children's } \\
\text { pronation and } \\
\text { supination using } \\
\text { acceleration and } \\
\text { angular velocity } \\
\text { sensors }\end{array}$ & $\begin{array}{l}\text { Pronation and } \\
\text { supination of the } \\
\text { forearms }\end{array}$ & $\begin{array}{l}\text { accuracy, } \\
\text { stability and } \\
\text { cooperativeness }\end{array}$ & $\begin{array}{l}\text { acceleration } \\
\text { and } \\
\text { angular } \\
\text { velocity sensor }\end{array}$ & $\begin{array}{l}\text { Result shows } \\
\text { difference } \\
\text { between } \\
\text { healthy } \\
\text { children and } \\
\text { ADHD } \\
\text { children }\end{array}$ & $\begin{array}{l}\text { Children } \\
\text { ( age } 7 \text { to } \\
\text { 12) and } \\
\text { adults(age } \\
\text { 21to 23) }\end{array}$ & $\begin{array}{l}\text { System has the } \\
\text { potential to } \\
\text { become } \\
\text { diagnostic } \\
\text { criteria for } \\
\text { developmental } \\
\text { disorders }\end{array}$ \\
\hline $\begin{array}{l}\text { [65]Investigating } \\
\text { prefrontal } \\
\text { hemodynamic } \\
\text { responses in ADHD } \\
\text { subtypes: A fNIRS } \\
\text { study }\end{array}$ & $\begin{array}{l}\text { Investigation } \\
\text { and Analysis }\end{array}$ & $\begin{array}{l}\text { Hemodynamic } \\
\text { response and } \\
\text { reaction time }\end{array}$ & $\begin{array}{l}\text { fNIRS, } \\
\text { Statistical } \\
\text { Analysis: }\end{array}$ & $\begin{array}{l}\text { Results } \\
\text { suggest a } \\
\text { novel path of } \\
\text { significant } \\
\text { interest } \\
\text { concerning } \\
\text { reliable } \\
\text { evaluation of } \\
\text { fNIRS and RT } \\
\text { studies in } \\
\text { ADHD } \\
\end{array}$ & $\begin{array}{l}\text { Children } \\
(14+9)\end{array}$ & $\begin{array}{l}\text { An ADHD-HI } \\
\text { group was less } \\
\text { compared the } \\
\text { others }\end{array}$ \\
\hline $\begin{array}{l}\text { [66]Gait Classification } \\
\text { for ADHD Children } \\
\text { Using Modified Dual } \\
\text { Tree } \\
\text { Complex Wavelet } \\
\text { Transform }\end{array}$ & $\begin{array}{l}\text { Recording of gait } \\
\text { Signals, 2-D } \\
\text { video }\end{array}$ & Frame Difference & $\begin{array}{l}\text { Gait, motion } \\
\text { detection, } \\
\text { binary image, } \\
\text { time } \\
\text { complexity, } \\
\text { image } \\
\text { subtraction }\end{array}$ & $\begin{array}{l}\text { This research } \\
\text { will lead to the } \\
\text { creation of the } \\
\text { cognitive } \\
\text { theory about } \\
\text { the ADHD } \\
\text { children }\end{array}$ & $\begin{array}{l}\text { Children } \\
\text { (15) }\end{array}$ & $\begin{array}{l}\text { The differences } \\
\text { were } \\
\text { found between } \\
\text { each group and it } \\
\text { results that there } \\
\text { is a change } \\
\text { in the gait among } \\
\text { ADHD and } \\
\text { normal is proved }\end{array}$ \\
\hline
\end{tabular}




\begin{tabular}{|c|c|c|c|c|c|c|}
\hline $\begin{array}{l}\text { [67] EEG Brain } \\
\text { Mapping and Brain } \\
\text { Connectivity Index for } \\
\text { Subtypes } \\
\text { Classification of } \\
\text { Attention Deficit } \\
\text { Hyperactivity Disorder } \\
\text { Children } \\
\text { During the Eye- } \\
\text { Opened Period }\end{array}$ & Classification & $\begin{array}{l}\text { 19- } \\
\text { channel EEG } \\
\text { data, Brain } \\
\text { mapping }\end{array}$ & $\begin{array}{l}\text { QEEG } \\
\text { techniques, } \\
\text { Coherence, } \\
\text { Phase Lag or } \\
\text { Phase } \\
\text { Difference }\end{array}$ & $\begin{array}{l}\text { System helps } \\
\text { psychiatrist, } \\
\text { psychologist, } \\
\text { neurofeedback } \\
\text { therapist, } \\
\text { occupational } \\
\text { therapist }\end{array}$ & $\begin{array}{l}\text { Children } \\
\text { (age 6,8,15) }\end{array}$ & $\begin{array}{l}\text { Result shows } \\
\text { abnormality of } \\
\text { the ADHD brain } \\
\text { map deviated } \\
\text { from the } \\
\text { normal range }\end{array}$ \\
\hline $\begin{array}{l}\text { [68] ELM-Based } \\
\text { Classification of } \\
\text { ADHD Patients Using } \\
\text { a } \\
\text { Novel Local Feature } \\
\text { Extraction Method }\end{array}$ & Feature extraction & $\begin{array}{l}\text { Brain fMRI } \\
\text { dataset, } \\
\text { DICCCOL-fMRI } \\
\text { data is a } 358 \times 230\end{array}$ & $\begin{array}{l}\text { Functional } \\
\text { interaction } \\
\text { patterns, } \\
\text { Bayesian } \\
\text { connectivity } \\
\text { change point } \\
\text { model, } \\
\text { ELM }\end{array}$ & $\begin{array}{l}\text { Method } \\
\text { achieved } \\
\text { better } \\
\text { classification } \\
\text { performance } \\
\text { compared to } \\
\text { the } \\
\text { existing } \\
\text { methods }\end{array}$ & $\begin{array}{l}\text { Children } \\
\text { (age group } \\
23+45)\end{array}$ & $\begin{array}{l}\text { Need more } \\
\text { experiments } \\
\text { would be carried } \\
\text { out to evaluate } \\
\text { local } \\
\text { features in } \\
\text { classification } \\
\text { problems on } \\
\text { neuroimaging }\end{array}$ \\
\hline
\end{tabular}

\section{DifFERENT SOlution METHODS FOR ADHD}

There are plenty of remedies were prescribed by different methods for ADHD, they might be and might not be best solution. A framework called Biofeedback based games [69] for children as a universal remedy for disorders, the method gives feedback to teacher the mood of student, then the teacher regulate the teaching in an optimal path. Table 10 gives the Summary of ADHD Solution methods.

An IOT [70] is an important tool for adult ADHD patients, tool assists adults by recording daily activities in mobile, and provides a better quality of to ADHD patients. Using EEG signal [71] cognitive capability of ADHD children were improved by $99.9 \%$. An augment reality [72] game assists ADHD children improve over the disorder, by providing interest, problem solving capability and susses in academics, need to add more levels for the existing game. Brain computer interface [73] game allows sustaining attention in ADHD children, results shows control of inattention, impulsiveness, good attitude in learning activities, decreasing disorder nature. A serious game [74] antonym assists to increase the attention on focused elements in everyday life for ADHD children, yet need to implement more mini games with other activities.

\section{CONCLUSION}

An ADHD disorder is the crucial problem in medical field for human being. It leads to many serious problems such as anxiety, depression, unfamiliar surroundings, difficulty in learning, etc. Patients require a proper treatment in the early of the disorder, else it creates a major trouble in future. Enormous work is done on ADHD, many research work completed, and still there is a scope for better solution for ADHD. The survey on ADHD includes combination of diagnosis/evaluation/analysis and treatment methods. Here it is summarised and categorized into different groups. The paper focuses on diverse areas of diagnosis and solution methods. The grouping may lead to add new diagnosis and treatment method in future. The different areas of research on ADHD are consolidated in here. It assists to enhance the diagnosis and treatment procedures further. The classification made in this paper may assist researchers to view ADHD problem in a broad sense.

Table 10. Summary of adhd solution methods

\begin{tabular}{|c|c|c|c|c|c|c|}
\hline Literature Work & $\begin{array}{l}\text { Treatment } \\
\text { Method }\end{array}$ & $\begin{array}{l}\text { Target } \\
\text { Features }\end{array}$ & $\begin{array}{l}\text { Related } \\
\text { Platform }\end{array}$ & $\begin{array}{l}\text { Treatment } \\
\text { Accuracy }\end{array}$ & $\begin{array}{l}\text { Application } \\
\text { Useful for }\end{array}$ & Merits/Demerits \\
\hline $\begin{array}{l}\text { [70] The Internet of } \\
\text { Things as a Helping } \\
\text { Tool in the } \\
\text { Daily Life of Adult } \\
\text { Patients with ADHD }\end{array}$ & Questionnaire & $\begin{array}{l}\text { Daily activities } \\
\text { of adults }\end{array}$ & $\begin{array}{l}\text { Internet of } \\
\text { Things, } \\
\text { Mhealth, mobile }\end{array}$ & $\begin{array}{l}\text { Result shows that } \\
\text { the tool has } \\
\text { demonstrated } \\
\text { a great potential } \\
\text { to help people } \\
\text { with ADHD }\end{array}$ & Adults & $\begin{array}{l}\text { Assists the daily } \\
\text { activities of an } \\
\text { adult person }\end{array}$ \\
\hline $\begin{array}{l}\text { [71]An Approach to } \\
\text { Measure and Improve } \\
\text { the Cognitive } \\
\text { Capability of } \\
\text { ADHD Affected } \\
\text { Children through EEG } \\
\mathrm{Si}\end{array}$ & $\begin{array}{l}\text { Plotting EEG } \\
\text { signals }\end{array}$ & Visualization & $\begin{array}{l}\text { Neural network } \\
\text { algorithm, } \\
\text { Single map } \\
\text { analysis, } \\
\text { Frequency map } \\
\text { analysis, 3-D } \\
\text { Plot }\end{array}$ & $\begin{array}{l}\text { Helps } \\
\text { toassessment of } \\
\text { learning and } \\
\text { enhance learning } \\
\text { capability }\end{array}$ & $\begin{array}{l}\text { Children } \\
\text { (age } 4 \text { to } 17 \text { ) }\end{array}$ & $\begin{array}{l}\text { This work has its } \\
\text { own social } \\
\text { importance and } \\
\text { scope for further } \\
\text { research }\end{array}$ \\
\hline
\end{tabular}




\begin{tabular}{|c|c|c|c|c|c|c|}
\hline $\begin{array}{l}\text { [72] Towards the } \\
\text { Improvement of } \\
\text { ADHD Children } \\
\text { through Augmented } \\
\text { Reality Serious } \\
\text { Games: } \\
\text { Preliminary Results }\end{array}$ & Training & Attention & $\begin{array}{l}\text { Serious games; } \\
\text { augmented } \\
\text { reality; } \\
\text { Augmented } \\
\text { Reality Serious } \\
\text { Games; } \\
\text { ATHYNOS } \\
\end{array}$ & $\begin{array}{l}\text { player's attention } \\
\text { and retention } \\
\text { increased, }\end{array}$ & $\begin{array}{l}\text { Children } \\
\text { (age 7-10) }\end{array}$ & $\begin{array}{l}\text { Augmented } \\
\text { Reality with } \\
\text { more difficulty } \\
\text { levels can be } \\
\text { added }\end{array}$ \\
\hline $\begin{array}{l}\text { [73]Design and } \\
\text { Creation of a BCI } \\
\text { Videogame to Train } \\
\text { Sustained Attention in } \\
\text { Children with ADHD }\end{array}$ & Video Game & $\begin{array}{l}\text { waiting ability, } \\
\text { planning ability, } \\
\text { ability to follow } \\
\text { instructions, } \\
\text { ability to } \\
\text { achieve } \\
\text { objectives }\end{array}$ & $\begin{array}{l}\text { BCI, } \\
\text { Neuromodulatio } \\
\text { n, Videogame, } \\
\text { Neurofeedback }\end{array}$ & $\begin{array}{l}\text { notable } \\
\text { improvement in } \\
\text { control of } \\
\text { inattention } \\
\text { impulsiveness }\end{array}$ & $\begin{array}{l}\text { Children } \\
\text { (age 7-11) }\end{array}$ & $\begin{array}{l}\text { The videogame } \\
\text { was created for } \\
\text { its use in public } \\
\text { or } \\
\text { private } \\
\text { educational } \\
\text { institution }\end{array}$ \\
\hline $\begin{array}{l}\text { [74] ANTONYMS: A } \\
\text { Serious Game for } \\
\text { Enhancing } \\
\text { Inhibition Mechanisms } \\
\text { in Children with } \\
\text { Attention } \\
\text { Deficit/Hyperactivity } \\
\text { Disorder (ADHD) }\end{array}$ & Video game & Attention & Serious Game & $\begin{array}{l}\text { an increase in the } \\
\text { ability to keep } \\
\text { attention focused } \\
\text { on the relevant } \\
\text { elements of } \\
\text { situations that } \\
\text { children face in } \\
\text { their everyday } \\
\text { life }\end{array}$ & $\begin{array}{l}\text { Children } \\
\text { (age } 8 \text { to 12) }\end{array}$ & $\begin{array}{l}\text { Implementation } \\
\text { of more mini } \\
\text { games is future } \\
\text { plan }\end{array}$ \\
\hline
\end{tabular}

\section{REFERENCES}

[1] F. Jimenez, T. Yoshikawa, T. Furuhashi, M. Kanoh and T. Nakamura, "Effects of Collaborative Learning between Educational-Support Robots and Children who Potential Symptoms of a Development Disability", 2016 Joint 8th International Conference on Soft Computing and Intelligent Systems (SCIS) and 17th International Symposium on Advanced Intelligent Systems (ISIS), Sapporo 2016, pp. 266-270. doi: 10.1109/SCISISIS. 2016.0064.

[2] K. Krishnaveni and E. Radhamani, "Diagnosis and evaluation of ADHD using Naïve Bayes and J48 classifiers," 2016 3rd International Conference on Computing for Sustainable Global Development (INDIACom), New Delhi, 2016, pp. 1809-1814.

[3] Commodari, Elena, "Preschool teacher attachment and attention skills", SpringerPlus, pp. 673, Vol 2, Dec. 2013.

[4] H. Heinrich, H. Dickhaus, A. Rothenberger, V. Heinrich and G. H. Moll, "Single-sweep analysis of event-related potentials by wavelet networks-methodological basis and clinical application," in IEEE Transactions on Biomedical Engineering, vol. 46, no. 7, pp. 867-879, July1999.doi: $10.1109 / 10.771199$

[5] B. Padmaja, V. V. Rama Prasad, K. V. N. Sunitha, "TreeNet analysis of human stress behavior using sociomobile data", Journal of Big Data, 2016, Volume 3, Number 1, Page 1

[6] Christof Loose, Frank Meyer, Reinhard Pietrowsky, "The Dusseldorf Illustrated Schema Questionnaire for Children (DISC)", Psicologia: Reflexão e Crítica, 2018, Volume 31, Number 1, Page 1

[7] S. Farzi, S. Kianian and I. Rastkhadive, "Diagnosis of attention deficit hyperactivity disorder using deep belief network based on greedy approach," 2017 5th International Symposium on Computational and Business Intelligence (ISCBI), Dubai, 2017, pp. 96-99. doi:10.1109/ISCBI.2017.8053552

[8] Z. Esmailpoor, A. M. Nasrabadi and S. Malayeri, "An auditory brainstem response-based expert system for ADHD diagnosis using recurrence qualification analysis and wavelet support vector machine," 2015 23rd Iranian Conference on Electrical Engineering, Tehran, 2015, pp. 6-10. doi: 10.1109/IranianCEE.2015.7146173
[9] Perricone, Giovannaand Morales, M. Regina and Anzalone, Germana, "Neurodevelopmental outcomes of moderately preterm birth: precursors of attention deficit hyperactivity disorder at preschool age", SpringerPlus, 2013, $12^{\text {th }}$ May, volume 2, Number 1,pages $=221$, issn 2193-1801,doi:10.1186/2193-1801-2-221

[10] Duffy, Anne, Horrocks, Julie, Doucette, Sarah , Keown Stoneman, Charles, Grof, Paul, Andreazza, Ana, Young, L. Trevor, "Immunological and neurotrophic markers of risk status and illness development in high-risk youth: understanding the neurobiological underpinnings of bipolar disorder", International Journal of Bipolar Disorders, 2014, Mar $31^{\mathrm{ST}}$, Volume 2 , number 1, pages $=4$, issn=2194-7511, doi=10.1186/2194-7511-2-4

[11] Abe, Jair Minoro, Lopes, Helder F. S., Nakamatsu, Kazumi, "Paraconsistent neurocomputing and brain signal analysis", Vietnam Journal of Computer Science", 2014, Nov $1^{\text {st }}$, volume 1, number 4, pages 219--230, issn 21968896, doi $=10.1007 /$ s40595-014-0022-9,

[12] C. Chen, Y. Tang, N. Zhang and J. Shin, "Neurofeedback based attention training for children with ADHD," 2017 IEEE 8th International Conference on Awareness Science and Technology (iCAST), Taichung, 2017, pp. 93-97. doi: 10.1109/ICAwST.2017.8256530

[13] Keown-Stoneman, Charles DG, Horrocks, Julie, Darlington, Gerarda A. , Goodday, Sarah, Grof, Paul, Duffy, Anne, "Multi-state models for investigating possible stages leading to bipolar disorder", International Journal of Bipolar Disorders, 2015, Feb $24^{\text {th }}$, Vol 3,No.1, pages $=5, \quad$ issn $=2194-7511, \quad$ doi $=" 10.1186 / \mathrm{s} 40345-014-$ 0019-4"

[14] Luciane da Rosa Piccolo,Adriane Xavier Arteche, Rochele Paz Fonseca ,Rodrigo Grassi-Oliveira, Jerusa Fumagalli Salles,'Influence of family socioeconomic status on IQ, language, memory and executive functions of Brazilian children", Psicol. Reflex. Crit. vol.29 Porto egre 2016 Epub June 20, 2016, ISSN 1678-7153

[15] Pisacco, Nelba Maria Teixeira, Sperafico, Yasmini Lais Spindle, Enricone, Jacqueline Raquel Bianchi, Guimar, Luciano Santos Pinto, Rohde, Luis Augusto, Dorneles, Beatriz Vargas, "Metacognitive interventions in text production and working memory in students with ADHD", Psicologia Reflex Critica, 2018, Feb $7^{\text {th }}$, Vol .31, no. 1, pages 5, Issn: 1678-7153,Doi:10.1186/s41155-017-00819 
[16] W. Wang, B. Hu, Z. Yao, M. Jackson, R. Liu and C. Liang, "Dysfunctional neural activity and connection patterns in attention deficit hyperactivity disorder: A resting state fMRI study," The 2013 International Joint Conference on Neural Networks (IJCNN), Dallas, TX, 2013, pp. 1-6. doi: 10.1109/IJCNN.2013.6707011

[17] Z. Yao et al., "Functional network disruption in attention deficit hyperactivity disorder," 2014 IEEE International Conference on Bioinformatics and Biomedicine (BIBM), Belfast, 2014, pp. 84-90. doi: 10.1109/BIBM.2014.6999273

[18] D. Z. Blandón, J. E. Muñoz, D. S. Lopez and O. H. Gallo, "Influence of a BCI neurofeedback videogame in children with ADHD. Quantifying the brain activity through an EEG signal processing dedicated toolbox," 2016 IEEE 11th Colombian Computing Conference(CCC),Popayan,2016,pp.1-8.doi: 10.1109/ColumbianCC.2016.7750788

[19] A. Allahverdy, A. M. Nasrabadi and M. R. Mohammadi, "Detecting ADHD children using symbolic dynamic of nonlinear features of EEG," 2011 19th Iranian Conference on Electrical Engineering, Tehran, 2011, pp. $1-4$.

[20] A. Alex, S. Coelli, A. M. Bianchi, L. Ponzini, E. Buzzi and M. P. Canevini, "EEG analysis of brain activity in attention deficit hyperactivity disorder during an attention task," 2017 IEEE 3rd International Forum on Research and Technologies for Society and Industry(RTSI),Modena,2017,pp.1-4.doi: 10.1109/RTSI.2017.8065955

[21] Demanuele, C.; James, C.J.; Sonuga-Barke, E.J.S.; Capilla, A.: 'Low frequency phase synchronisation analysis of MEG recordings from children with ADHD and controls using single channel ICA', IET Conference Proceedings, 2008, p. 111-111, DOI: 10.1049/cp:20080428 IET Digital Library

[22] Fuermaier, Anselm BM, Tucha, Lara, Mueller, Anna K, Koerts, Janneke,Hauser, Joachim, Lange, Klaus W., Tucha, Oliver, "Stigmatization in teachers towards adults with attention deficit hyperactivity disorder", Springer Plus, 2014, Jan $14^{\text {th }}$, Vol. 3, No. 1, Pages 26, issn:21931801, Doi:10.1186/2193-1801-3-26

[23] H. Chen, J. Yan, Y. Gu, Y. Song and X. Li, "Mutual information analysis of EEG of children with attentiondeficit/hyperactivity disorder," 2017 Chinese Automation Congress (CAC), Jinan, 2017, pp. 2342-2347.doi: 10.1109/CAC.2017.8243167

[24] S. Jaiswal, M. F. Valstar, A. Gillott and D. Daley, "Automatic Detection of ADHD and ASD from Expressive Behaviour in RGBD Data," 2017 12th IEEE International Conference on Automatic Face \& Gesture Recognition (FG 2017), Washington, DC, 2017, pp. 762769. doi: 10.1109/FG.2017.95

[25] S. Khoshnoud, M. Shamsi and M. A. Nazari, "Non-linear EEG analysis in children with attention-deficit/ hyperactivity disorder during the rest condition," 2015 22nd Iranian Conference on Biomedical Engineering (ICBME), Tehran, 2015, pp. 87-92. doi: 10.1109/ICBME.2015.7404122

[26] S. Iyer, R. S. Mishra, S. P. Kulkami and D. Kalbande, "Assess autism level while playing games," 2017 2nd International Conference on Communication Systems, Computing and IT Applications (CSCITA), Mumbai, 2017, pp. 42-47. doi: 10.1109/CSCITA.2017.8066573

[27] Xiao, Cao, Bledsoe, Jesse, Wang, Shouyi, Chaovalitwongse, Wanpracha Art, Mehta, Sonya,
Semrud-Clikeman, Margaret, Grabowski, Thomas", "An integrated feature ranking and selection framework for ADHD characterization", Brain Informatics, 2016, Sep $1^{\text {st }}$ Vol 3, No.3, Pages 145-155, issn: 2198-4026, doi:10.1007/s40708-016-0047-1

[28] B. Miao and Y. Zhang, "A feature selection method for classification of ADHD," 2017 4th International Conference on Information, Cybernetics and Computational Social Systems (ICCSS),Dalian,2017,pp.21-25.doi: 10.1109/ICCSS.2017.8091376

[29] F. Fahimi, C. Guan, W. B. Goh, K. K. Ang, C. G. Lim and T. S. Lee, "Personalized features for attention detection in children with Attention Deficit Hyperactivity Disorder," 2017 39th Annual International Conference of the IEEE Engineering in Medicine and Biology Society $(E M B C)$, Seogwipo, 2017, pp. 414-417.doi: 10.1109/EMBC.2017.8036850

[30] M. Á. Bautista et al., "A Gesture Recognition System for Detecting Behavioral Patterns of ADHD," in IEEE Transactions on Cybernetics, vol. 46, no. 1, pp. 136-147, Jan. 2016.doi: 10.1109/TCYB.2015.2396635

[31] M. Tudosie, E. Truță, A. M. Davițoiu, A. M. Mitu and A. A. Bojescu, "Optoelectronics method for determining the cobalt involved in symptoms of attention deficit hyperactivity disorder," 2017 9th International Conference on Electronics, Computers and Artificial Intelligence (ECAI), Targoviste, 2017, pp. 1-4.doi: 10.1109/ECAI.2017.8166474

[32] R. Gabriel, M. Machado Spindola, A. Mesquita and A. Zerbetto Neto, "Identification of ADHD Cognitive Pattern Disturbances Using EEG and Wavelets Analysis," 2017 IEEE 17th International Conference on Bioinformatics and Bioengineering (BIBE), Washington, DC, 2017, pp. 157-162.doi: 10.1109/BIBE.2017.00-62

[33] Konda, Yukiko, Miura, Yui, Oi, Manabu, "Causes of academic and behavioral difficulties among JapaneseBrazilian students: cognitive, linguistic and parental education factors", Multilingual Education, 2015, Apr $10^{\text {th }}$, Vol 5, No. 1, Pages 2, Issn:2191-5059, Doi: 10.1186/s13616-015-0022-9",

[34] Pardeep Kumar Aggarwal, Vanita Jain, Vivekanand Jha, "Genes, chromosomes and disease", Genomic Medicine, 2008, 2008, Dec $1^{\text {st }}$, Vol.2, No.2, Pages: 351-380, Issn:1871-7942, doi:10.1007/s11568-009-9098-1

[35] Chang, Suhua, Zhang, Weina, Gao, Lei, Wang, Jing","Prioritization of candidate genes for attention deficit hyperactivity disorder by computational analysis of multiple data sources", Protein Cell, 2012, Jul 1 ${ }^{\text {st }}$, Vol. 3, No.7, pages:526--534, Issn:1674-8018, Doi:10.1007/s13238-012-2931-7

[36] J. Yao, "Mother Smoking During Pregnancy and ADHD in Children," 2017 IEEE 33rd International Conference on Data Engineering (ICDE), San Diego, CA, 2017, pp. 1515-1522. doi: 10.1109/ICDE.2017.222

[37] Anca Domuta, Imre Pentek, "Implicit Learning in ADHD Preschool Children", Implicit learningandADHD,2003, http://citeseerx.ist.psu.edu/viewdoc/download?doi=10.1.1. $125.5606 \&$ rep $=$ rep $1 \&$ type $=$ pdf

[38] C. Chaiyanan, K. Iramina, T. Angsuwatanakul and B. Kaewkamnerdpong, "Response time analysis on implicit learning induced by cognitive tasks toward developing ADHD treatment," $201710^{\text {th }}$ Biomedical Engineering International Conference (BMEiCON), Hokkaido, 2017, pp. 1-5. doi: 10.1109/BMEiCON.2017.8229133

[39] Saba, Leslie, Byrne, Alison, Mulligan, Aisling,"Child art psychotherapy in CAMHS: Which cases are referred and 
which cases drop out?", SpringerPlus, 2016, Oct $19^{\text {th }}$, Vol.5, No. 1, Pages:1816, issn:2193-1801, doi="10.1186/s40064-016-3509-2",

[40] D. A. Rohani, H. B. D. Sorensen and S. Puthusserypady, "Brain-computer interface using P300 and virtual reality: A gaming approach for treating ADHD," 2014 36th Annual International Conference of the IEEE Engineering in Medicine and Biology Society, Chicago, IL,2014,pp.3606-3609.doi:

10.1109/EMBC.2014.6944403

[41] Rohani, Darius A, Puthusserypady, Sadasivan, "BCI inside a virtual reality classroom: a potential training tool for attention", EPJ Nonlinear Biomedical Physics, 2015, Dec $24^{\text {th }}$, Vol. 3, No.1, Pages:12, issn:21950008,doi="10.1140/epjnbp/s40366-015-0027-z"

[42] H. Lee, Y. Li, S. Yeh, Y. Huang, Z. Wu and Z. Du, "ADHD assessment and testing system design based on virtual reality," 2017 2nd International Conference on Information

Technology(INCIT),Nakhonpathom,2017,pp.1-5.doi: 10.1109/INCIT.2017.8257860

[43] S. Yeh, C. Tsai, Y. Fan, P. Liu and A. Rizzo, "An innovative ADHD assessment system using virtual reality," 2012 IEEE-EMBS Conference on Biomedical Engineering and Sciences,Langkawi,2012,pp.78-83.doi: 10.1109/IECBES.2012.6498026

[44] M. P. Craven, Z. Young, L. Simons, H. Schnädelbach and A. Gillott, "From Snappy App to Screens in the Wild: Gamifying an Attention Deficit Hyperactivity Disorder Continuous Performance Test for Public Engagement and Awareness," 2014 International Conference on Interactive Technologies and Games, Nottingham, 2014, pp. 36-43.doi: 10.1109/iTAG.2014.12

[45] H. Tobar-Muñoz, R. Fabregat and S. Baldiris, "Using a videogame with augmented reality for an inclusive logical skills learning session," 2014 International Symposium on Computers in Education (SIIE), Logrono, 2014, pp. 189194.doi: 10.1109/SIIE.2014.7017728

[46] H. T. Muñoz, S. B. Navarro and R. Fabregat, "Gremlings in My Mirror: An Inclusive AR-Enriched Videogame for Logical Math Skills Learning," 2014 IEEE 14th International Conference on Advanced Learning Technologies, Athens, 2014, pp. 576-578.doi: 10.1109/ICALT.2014.168

[47] L. Gómez and R. M. Carro, "Adaptive Training of Children with Attention Deficit Hyperactivity Disorder through Multi-touch Surfaces," 2014 IEEE 14th International Conference on Advanced Learning Technologies, Athens, 2014, pp. 561-563, doi: 10.1109/ICALT.2014.164

[48] M. Clark-Turner and M. Begum, "Deep recurrent Qlearning of behavioral intervention delivery by a robot from demonstration data," 2017 26th IEEE International Symposium on Robot and Human Interactive Communication (RO-MAN), Lisbon, 2017, pp. 1024-1029. doi: 10.1109/ROMAN.2017.8172429

[49] M. Frutos-Pascual and B. G. Zapirain, "Guided crossword-puzzle games aimed at children with Attentional Deficit: Preliminary results," 2014 Computer Games: AI, Animation, Mobile, Multimedia, Educational and Serious Games (CGAMES), Louisville, KY, 2014, pp. 1-4.doi: 10.1109/CGames.2014.6934137

[50] Natalia Vilor-Tejedor, Juan R. Gonzalez, and M. Luz Calle. 2016. Efficient and Powerful Method for Combining P-Values in Genome-Wide Association Studies. IEEE/ACM Trans. Comput. Biol.
Bioinformatics 13, 6 (November 2016), 1100-1106. DOI: https://doi.org/10.1109/TCBB.2015.2509977

[51] N. Pandria, D. Spachos and P. D. Bamidis, "The future of mobile health ADHD applications," 2015 International Conference on Interactive Mobile Communication Technologies and Learning (IMCL), Thessaloniki, 2015, pp. 279-282.doi: 10.1109/IMCTL.2015.7359603

[52] T. S. Petrenko, V. S. Kublanov, A. A. Petrenko and K. J. Retyunskiy, "Application of the non-invasive adaptive neuroelectrostimulation device for treatment of cognitive impairment in the model of attention deficit hyperactivity disorder," 2016 Cognitive Sciences, Genomics and Bioinformatics (CSGB), Novosibirsk, 2016, pp. 1-5. doi: 10.1109/CSGB.2016.7587682

[53] Rosenblum, Sara , Yom-Tov, Elad, "Seeking web-based information about attention deficit hyperactivity disorder: where, what, and when", Journal of medical Internet research, Vol . 19, No. 4, 2017, JMIR Publications Inc.

[54] S. Okada, N. Shiozawa and M. Makikawa, "Body movement in children with ADHD calculated using video images," Proceedings of 2012 IEEE-EMBS International Conference on Biomedical and Health Informatics, Hong Kong, 2012, pp. 60-61.doi: 10.1109/BHI.2012.6211505

[55] S. Okada, N. Shiozawa and M. Makikawa, "Body movement in children with ADHD calculated using video images," Proceedings of 2012 IEEE-EMBS International Conference on Biomedical and Health Informatics, Hong Kong, 2012, pp. 60-61.doi: 10.1109/BHI.2012.6211505

[56] B. Park, J. Kim and H. Park, "Differences in connectivity patterns between child and adolescent attention deficit hyperactivity disorder patients," 2016 38th Annual International Conference of the IEEE Engineering in Medicine and Biology Society (EMBC), Orlando, FL, 2016,pp.1127-1130.doi: 10.1109/EMBC.2016.7590902

[57] B. A. Rahadian, C. Dewi and B. Rahayudi, "The performance of Genetic Algorithm Learning Vector Quantization 2 Neural Network on identification of the types of Attention Deficit Hyperactivity Disorder," 2017 International Conference on Sustainable Information Engineering and Technology (SIET), Malang, 2017, pp. 337-341.doi: 10.1109/SIET.2017.8304160

[58] G. Yang, J. Liu, F. Xu and Z. Liu, "Sustained attention differences between children with ADHD and normal children based on auditory-visual stimulation," 2012 2nd International Conference on Consumer Electronics, Communications and Networks (CECNet), Yichang, 2012,pp.2922-2924.doi: 10.1109/CECNet.2012.6201980

[59] J. Liu, G. Yang, F. Xu and M. Zhou, "The differences in coordination between children with ADHD and healthy children based on two-way ANOVA analysis," 2012 2nd International Conference on Consumer Electronics, Communications and Networks (CECNet),Yichang,2012,pp.2972-2975.doi: 10.1109/CECNet.2012.6201900

[60] J. L. L. Marcano, M. A. Bell and A. A. L. Beex, "Classification of ADHD and non-ADHD using AR models," 2016 38th Annual International Conference of the IEEE Engineering in Medicine and Biology Society $(E M B C)$, Orlando, FL, 2016, pp. 363-366.doi: 10.1109/EMBC.2016.7590715

[61] Hao, A.J.; He, B.L.; Yin, C.H.: 'Discrimination of ADHD children based on Deep Bayesian Network', IET Conference Proceedings, 2015, p. 6 .6 ., DOI: 10.1049/cp.2015.0764IETDigitalLibrary,https://digitallibr ary.theiet.org/content/conferences/10.1049/cp.2015.0764 
[62] K. Chu, H. Huang and Y. Huang, "Machine learning approach for distinction of ADHD and OSA," 2016 IEEE/ACM International Conference on Advances in Social Networks Analysis and Mining (ASONAM), San Francisco, CA, 2016, pp. 1044-1049.doi: 10.1109/ASONAM.2016.7752370

[63] M. Uluyagmur-Ozturk et al., "ADHD and ASD Classification Based on Emotion Recognition Data," 2016 15th IEEE International Conference on Machine Learning and Applications (ICMLA), Anaheim, CA, 2016, pp. 810-813.doi: 10.1109/ICMLA.2016.0145

[64] M. Kaneko et al., "The comparison with the function of children's pronation and supination using acceleration and angular velocity sensors," The 5th 2012 Biomedical Engineering International Conference, Ubon Ratchathani, 2012, pp. 1-5, doi: 10.1109/BMEiCon.2012.6465423

[65] M. Altinkaynak et al., "Investigating prefrontal hemodynamic responses in ADHD subtypes: A fNIRS study," 2017 10th International Conference on Electrical and Electronics Engineering (ELECO), Bursa, 2017, pp. 611-614.

[66] D. Sudha and M. P. Rani, "Gait Classification for ADHD Children Using Modified Dual Tree Complex Wavelet Transform," 2017 World Congress on Computing and Communication Technologies (WCCCT), Tiruchirappalli, 2017, pp. 215-218.doi: 10.1109/WCCCT.2016.60

[67] S. Rodrak and Y. Wongsawat, "EEG brain mapping and brain connectivity index for subtypes classification of attention deficit hyperactivity disorder children during the eye-opened period," 2013 35th Annual International Conference of the IEEE Engineering in Medicine and Biology Society (EMBC), Osaka, 2013, pp. 7400-7403.doi: 10.1109/EMBC.2013.6611268

[68] Yang Li, Zhichao Lian, Min Li, Zhonggeng Liu, Liang Xiao and Zhihui Wei, "ELM-based classification of ADHD patients using a novel local feature extraction method," 2016 IEEE International Conference on Bioinformatics and Biomedicine (BIBM), Shenzhen, 2016, pp. 489-492. doi: 10.1109/BIBM.2016.7822566

[69] D. Bodolai, L. Gazdi, B. Forstner and L. Szegletes, "Supervising Biofeedback-based serious games," 2015 6th IEEE International Conference on Cognitive Infocommunications (CogInfoCom),Gyor,2015,pp.273278.doi: 10.1109/CogInfoCom.2015.7390603

[70] C. S. Fujiwara, C. M. Aderaldo, R. H. Filho and D. A. A. Chaves, "The Internet of Things as a Helping Tool in the Daily Life of Adult Patients with ADHD," GLOBECOM 2017 - 2017 IEEE Global Communications Conference, Singapore, 2017, 2017 p. 1-6.doi: 10.1109/GLOCOM.2017.8254442

[71] C. S and V. K, "An Approach to Measure and Improve the Cognitive Capability of ADHD Affected Children Through EEG Signals," 2018 IEEE 18th International Conference on Advanced Learning Technologies (ICALT), Mumbai, 2018, pp. 314-318.doi: 10.1109/ICALT.2018.00079

[72] D. Avila-Pesantez, L. A. Rivera, L. Vaca-Cardenas, S. Aguayo and L. Zuñiga, "Towards the improvement of ADHD children through augmented reality serious games: Preliminary results," 2018 IEEE Global Engineering Education Conference (EDUCON), Tenerife, 2018, pp.843-848.doi: 10.1109/EDUCON.2018.8363318

[73] J. E. Muñoz, D. S. Lopez, J. F. Lopez and A. Lopez, "Design and creation of a BCI videogame to train sustained attention in children with ADHD," 2015 10th Computing Colombian Conference (10CCC), Bogota,
2015, pp. 194-199. doi: 10.1109/ColumbianCC.2015.7333431

[74] V. Colombo, D. Baldassini, S. Mottura, M. Sacco, M. Crepaldi and A. Antonietti, "Antonyms: A serious game for enhancing inhibition mechanisms in children with Attention Deficit/Hyperactivity Disorder (ADHD)," 2017 International Conference on Virtual Rehabilitation (ICVR), Montreal, QC, 2017, pp. 1-2.doi: 10.1109/ICVR.2017.8007457

Authors' Profiles

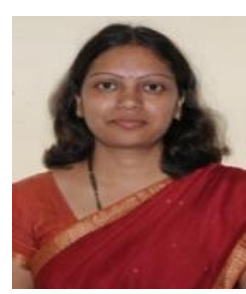

Sumathi M, is a Information Science and Engineering graduate. She completed her M.Tech degree in Computer Science \& Engineering from RVCE, Bengaluru. She is working in the Department of Information Science and Engineering, Don Bosco Institute of Technology, Bengaluru.

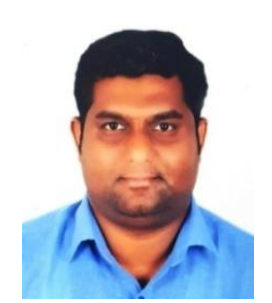

Dr.Nagaraj G Cholli is a Computer Science and Engineering graduate. He also holds the M.Tech degree in Computer Science \& Engineering from IIT-Roorkee. $\mathrm{He}$ obtained $\mathrm{PhD}$ from Visvesvaraya Technological University, Belagavi, Karnataka. He presently works as Associate Professor at Department of Information Science and Engineering, R.V College of Engineering, Bengaluru, Karnataka, India. He has a total of 13 years of experience in teaching, research, industry in India and abroad. He has published several research articles in International journals and presented papers at International Conferences. He is active in research, has filed patents and guiding several $\mathrm{PhD}$ scholars. He is also a life member of ISTE and CSI society.

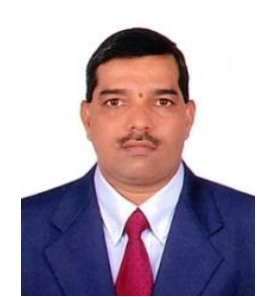

Dr. Shantharam Nayak currently working as professor in ISE department at R.V. College of Engineering, Bangalore. Nayak has 26 years of rich academic experience in teaching Under Graduate \& Post Graduate students and Research. His research activity and guidance credited him with Publication of 37 papers in International refereed Journal, 09 in National conference and 06 in International conference. Prof. Nayak is a Life member of ISTE, Senior Life member of CSI, Fellow of IE, Associate member of ACM-India, Member of IAENG. Prof. Nayak received Recognition \& Honor from Computer Society of India as Significant contribution award, Longest Continuous SBC award, Patron award. Professional body membership in various areas such as Life Member - Indian Society for Technical Education [ MISTE ], Senior Life Member - CSI [ SLMCSI ], Fellow of Institution of Engineers [ FIE ], Associate Member of ACM- India, Member of International Association of Engineers. 
How to cite this paper: Sumathi M, Nagaraj G Cholli, Shantharam Nayak, "Classification of Attention Deficit Hyperactivity Disorder (ADHD) Considering Diagnosis and Treatment", International Journal of Modern Education and Computer Science(IJMECS), Vol.11, No.6, pp. 26-42, 2019.DOI: 10.5815/ijmecs.2019.06.04 